\title{
U.S. Current Account Adjustment: An Appraisal
}

SINCE THE DOLLAR's decline in 1985, opinion has been divided about prospects for the U.S. trade deficit. Pessimists have argued that the weak industrial competitiveness of the United States and the barriers against its exports, particularly in Japan, prevent the U.S. trade deficit from significantly responding to the dollar's depreciation. These views reject other economists' explanations of the trade deficit, which have emphasized the role played by macroeconomic factors rather than foreign protectionism and industrial policies. Some other "pessimistic", economists have argued, on empirical grounds, that the response of the trade deficit would be small because importers have been unusually willing to absorb the impact of the weaker dollar in their profit margins. Still others have argued, on theoretical grounds, that the strong, pre1985 dollar itself could have damaged the economy's capacity to respond to the eventual fall of the exchange rate-a phenomenon known as "hysteresis." ${ }^{1}$ Hysteresis occurs, according to these views, because the appreciation of the dollar forces U.S. firms to reduce capacity and induces foreign firms to invest in distribution facilities in the United States. Therefore, when the dollar returns to lower levels, U.S. firms have less industrial capacity than when the cycle began while foreigners remain entrenched with "beachheads" in the U.S. market. Moreover, once foreigners have entered the market, U.S. firms find their own pricing power permanently reduced. ${ }^{2}$

This paper reflects work in progress on my study of U.S. manufacturing, financed by the Ford Foundation. I would like to thank Mariko Noda and Kashif Mansori for superb research assistance, and Charles $\mathrm{L}$. Schultze for comments.

1. See Baldwin (1988); Dixit (1989a, 1989b); Krugman (1989a, pp. 36-75).

2. In addition, those using an absorption approach have argued that without major 
Optimists, by contrast, have argued that conventional models systematically underestimate the long-run impact of exchange rate shifts. Because conventional estimation techniques operate with extremely long lags, they aliegedly cannot pick up the effects of exchange rate shifts. Proponents of this view have bolstered their case with studies that compare absolute costs of production internationally. The broadest of the studies, based on purchasing power parity (PPP) calculations, suggests that by 1987 the dollar had become much too weak. ${ }^{3}$ Studies that focus more narrowly on manufacturing costs indicate that unit costs in the United States have been considerably lower than those in other industrial countries. ${ }^{4}$ Other grounds for optimism have been improved U.S. productivity growth in manufacturing in the 1980s and increased foreign investment in U.S. manufacturing, which has raised the possibilities for import substitution.

Macroeconomic modelers who use conventional techniques have fallen between the two extremes. While they had, at one point, estimated that the dollar's decline would result in a substantially improved current account by 1989 , they also indicated that if growth rates in the United States and the rest of the world were to be the same and if no additional real depreciation was assumed, the current account deficit was unlikely to fall below $\$ 110$ billion. ${ }^{5}$

As it happened, in the immediate aftermath of the dollar's decline in 1985 the U.S. current account deficit continued to grow, increasing from $\$ 122.3$ billion in 1985 to $\$ 162.3$ billion in 1987 . It appeared as if the pessimists were correct. ${ }^{6}$ But since 1987 , the deficit has been shrinking, having fallen to an annualized figure of $\$ 79.3$ billion by the first half of

reductions in the fiscal deficit, the current account would show only limited improvement. Sachs (1988), for example, argues that the trade balance improves by about 40 percent of any decline in the budget deficit. The decline in the fiscal deficit between 1986 and 1988, by 1.5 percent of GNP, was insufficient to eliminate the trade deficit. According to McKinnon (1984), who uses an absorption framework, in a world of capital mobility, exchange rate changes are both unnecessary and unlikely to affect the current account. For a rejection of this view see Krugman (1989a, pp. 19-35).

3. According to the OECD, in 1987, the PPP value of the dollar was 213 Japanese yen (the actual exchange rate was 145); 2.5 deutsche marks (actual rate was 1.8); 7.4 French francs (actual rate was 6.0). See OECD, Main Economic Indicators, various issues.

4. See, for example, Hooper (1989).

5. See Bryant (1988). Cline (1989) projected a base-case current account deficit of $\$ 124.4$ billion in 1990 .

6. See, for example, Krugman and Baldwin (1987). 
1990. Does this recent behavior refute those pessimists who have been arguing that major declines in the dollar or other structural changes should have been required for the trade balance to fall? Does it support the optimists who suggest that conventional model builders have seriously underestimated the long-run boost current exchange rates would provide? Is the current account likely to continue its decline, even without further depreciation of the dollar? ${ }^{7}$

In this paper, I address these questions and present evidence supporting a view of the trade adjustment process similar to the one described by conventional modelers. In order to evaluate recent trade performance more clearly, I first adjust the data for measurement problems associated with computer prices. With the cleaner data, I use equations that are estimated over the pre-1985 period to track U.S. trade performance in the second half of the 1980s. My results indicate that hysteresis and other structural factors have not inhibited the adjustment process. Trade prices have responded symmetrically to both the dollar's appreciation and its depreciation. In addition, trade volumes have responded predictably to relative prices and economic activity. In the second half of the 1980s, the U.S. economy grew sufficiently slowly, relative to its trading partners, to offset long-run growth in the trade deficit that might have resulted from differences in activity elasticities. If the growth differential of the past three years continues and relative prices remain constant, the U.S. balance of trade in goods and services (excluding oil imports and agricultural exports) should change very little.

In the last part of the paper I look at two other issues that are often raised in discussions about the U.S. balance of payments. First, there is no evidence to support the claim that U.S.-Japanese trade has been particularly unresponsive to the price of the dollar. Second, some evidence indicates that the real burden of the rise in U.S. international indebtedness has been lower than expected.

\section{Trade Performance}

As reported in table 1, the U.S. trade deficit in goods and services has been shrinking steadily since 1987 . The merchandise trade deficit,

7. For a recent treatment of these questions, see Mann (1990). 


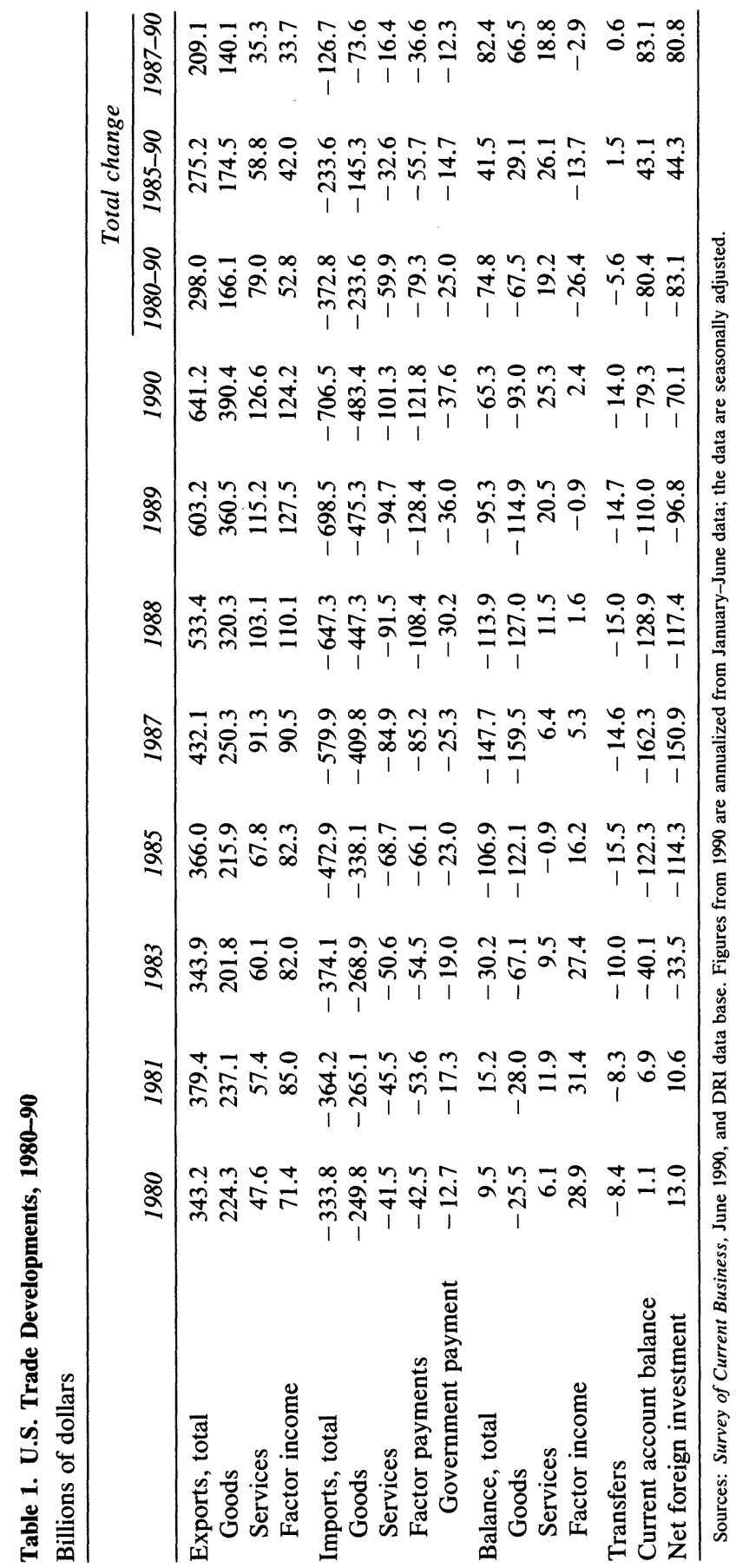


measured on a national income accounts basis, has declined from a peak level of $\$ 159.5$ billion in 1987 to $\$ 114.9$ billion in 1989 and $\$ 93.0$ billion in the first half of 1990 . Since 1987, the surplus in nonfactor income services (simply referred to as services, unless otherwise noted) increased $\$ 18.8$ billion. Surprisingly, for a nation that borrowed an additional $\$ 284.3$ billion between the end of 1987 and mid-1990, the balance in net factor payments (including government interest) fell only $\$ 2.9$ billion. Thus, the $\$ 83.1$ billion decline in the current account deficit mirrored the $\$ 82.4$ billion increase in the balance for goods and services. ${ }^{8}$

Since 1987, the trade balance has increased in virtually all major enduse categories except for petroleum products and computers. The largest improvements have been in capital goods, up $\$ 34.6$ billion, about half of which is aircraft; nonpetroleum industrial supplies, up $\$ 19.7$ billion; and services, up $\$ 18.8$ billion. Table 2 shows the trade figures by end-use category.

The behavior of petroleum imports and agricultural exports is sufficiently idiosyncratic as to warrant separate treatment. Accordingly, this paper will concentrate on the trade balance in goods and services excluding oil imports and agricultural exports (the nonoil and nonagricultural, or NONA, balance). The exclusions do not alter the size of the deficit changes. Between 1987 and the first half of 1990, the respective declines in the trade deficit are similar whether oil imports and agricultural exports are included or not.

\section{Measurement of Computer Prices}

One other complicating feature of the data is the peculiar treatment of computer prices in the trade accounts. ${ }^{9}$ Table 3 shows the effect of including and excluding computers when changes in the principal trade aggregates-nonagricultural exports and nonoil imports-are broken

8. Thus, Cline projects a decline in U.S. net foreign income from 1987 to 1992 of $\$ 39$ billion as net external debt rises by $\$ 513.0$ billion between the end of 1987 and the end of 1991; in an alternative model, he calculates an even larger decline in net earnings from factor services. See Cline (1989).

9. See Citrin (1989) and Meade (forthcoming). 


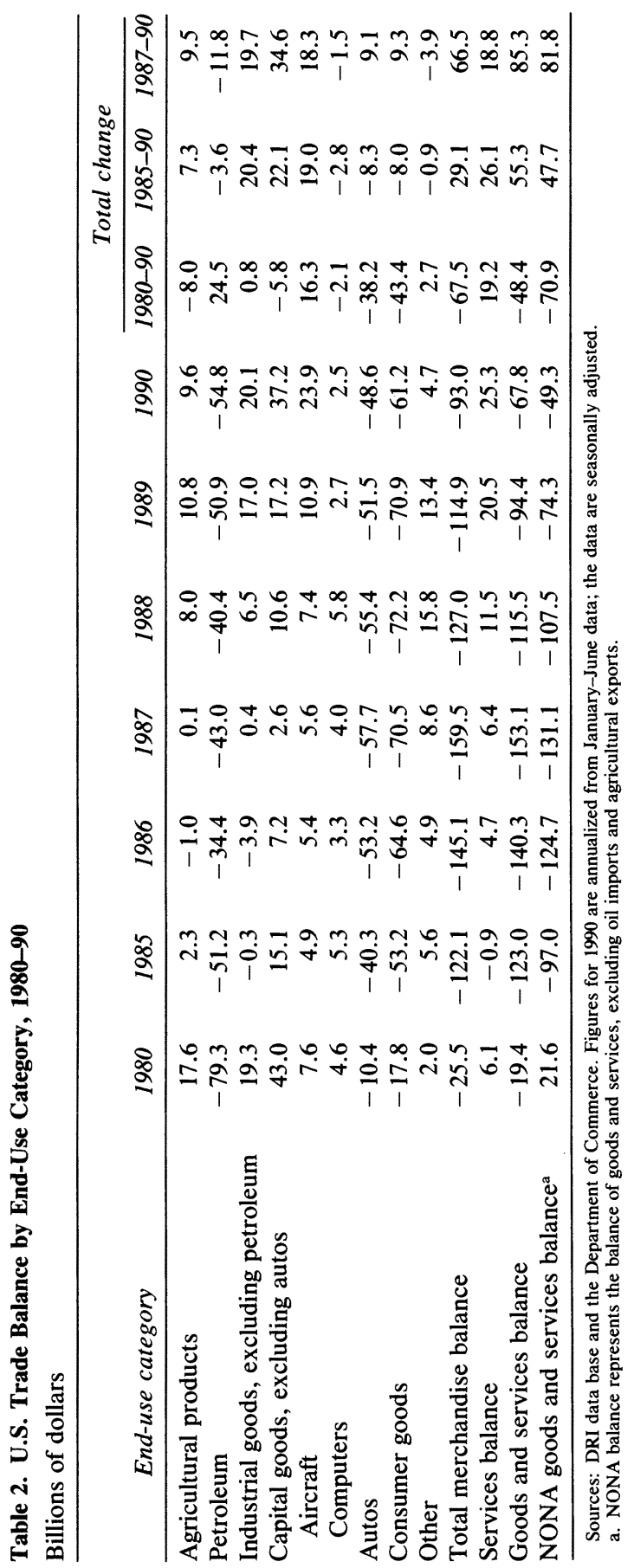


Table 3. Effect of Computers on Changes in U.S. Trade, 1980-90 Percent

\begin{tabular}{crrr}
\hline Category & Measure & $\begin{array}{c}\text { Including } \\
\text { computers }\end{array}$ & $\begin{array}{c}\text { Excluding } \\
\text { computers }\end{array}$ \\
\hline Nonagricultural exports & value & 74.4 & 73.0 \\
& price deflator & 12.0 & 27.7 \\
\multirow{3}{*}{ Nonoil imports } & quantity & 62.5 & 45.3 \\
& value & 94.8 & 92.5 \\
Trade balance & price deflator & 10.3 & 23.8 \\
& quantity & 84.5 & 68.7 \\
& value & -20.4 & -19.5 \\
& price deflator & -1.7 & 3.9 \\
& quantity & -22.0 & -23.4 \\
\hline
\end{tabular}

Sources: Values and implicit price deflators are BEA data taken from DRI and OECD data bases. Quantities are calculated from value and price indexes. Percent changes are calculated from the differences in logarithms in each category from the beginning to the end of each period.

down into changes in prices and quantities. ${ }^{10}$ Interestingly, over the decade the rise in the value of imports exceeds the value of exports by around 20 percent, whether or not computers are included. ${ }^{11}$ One must look more closely, at the price and volume changes, in order to see the impact of computers. While export and import prices, as measured by their deflators in the GNP accounts, increased by 12.0 and 10.3 percent respectively, the volume of imports rose 22.0 percentage points more than the volume of exports. These findings suggest the presence of some measurement problem. In particular, these data indicate that import and export prices rose much less than the U.S. producer price index for all finished goods, which rose 33.6 percent over this period. The suspicions are confirmed when computers are excluded from the data, as in the last column of table 3 . The results show that export and import deflators rise

10. Expressing the deficit as a ratio $(C)$ of nonagricultural exports to nonoil imports allows a logarithmic decomposition of changes into price and quantity components,

$$
\begin{aligned}
\text { if } C & =V_{x} / V_{m}, \\
\text { then } \ln C & =\ln V_{x}-\ln V_{m}, \\
& =\ln Q_{x}+\ln P_{x}-\ln Q_{m}-\ln P_{m} ; \\
\text { and, } \Delta \ln C & =\Delta \ln Q_{x}+\Delta \ln P_{x}-\Delta \ln Q_{m}-\Delta \ln P_{m} .
\end{aligned}
$$

11. In 1980, when the ratio between nonagricultural exports and nonoil imports was 1.1 , the NONA balance was a surplus of $\$ 21.6$ billion. By the first half of 1990 , the ratio was 0.87 and the NONA deficit stood at $\$ 49.3$ billion. 
much faster when computers are excluded, while the growth in export and import volumes is correspondingly reduced.

Computers have such a large impact because the nominal values of computer exports and computer imports have grown rapidly while the relative price of computers has declined drastically. This unusual behavior can be explained by the dramatic technical change experienced by the computer industry; this phenomenon contributes to the measurement problems seen in the trade data. To estimate the volumes of the computer trade, the Bureau of Economic Analysis (BEA) has constructed a hedonic price index for computers, and uses this one index to deflate the value of computer exports, computer imports, and producers durable equipment. This treatment of computers by the BEA makes it difficult to interpret U.S. trade data. As shown in table 4, the BEA index, which uses 1982 as its base year, had fallen to 29 by 1990 . This decline in the deflator has produced an explosive increase in the estimated volume of computer exports and imports. As a result, the overall deflators for exports and imports of goods and services have risen more slowly. Furthermore, because exports and imports of computers have both risen, the effect on the trade balance is less dramatic. Over the decade, a $\$ 2.1$ billion worsening in the nominal trade balance becomes a $\$ 4.6$ billion improvement when measured in 1982 prices.

The effect of computers on broader price indexes poses problems for most models that try to explain trade performance by estimating trade volumes and prices separately. It is no wonder that, as Ellen Meade has shown, models in which computers are disaggregated outperform those in which they are not. ${ }^{12}$ It is also not surprising that analysts who have tried to explain trade price behavior using the official deflators have found peculiarities after 1985 . The failure of the equations to predict prices accurately has presented major forecasting problems. ${ }^{13}$ As it happens, some models based on these deflators had price elasticities close to one, and so were relatively accurate in forecasting trade values, since price and quantity errors offset one another. ${ }^{14}$

Daniel Citrin as well as Peter Hooper and Catherine Mann shows that when fixed-weight price indexes, which include the hedonic measures of computer prices, are used in place of implicit deflators, most econo-

12. Meade (forthcoming).

13. See the discussion of the Hooper-Helkie model in Cline (1989).

14. Bryant (1988). 


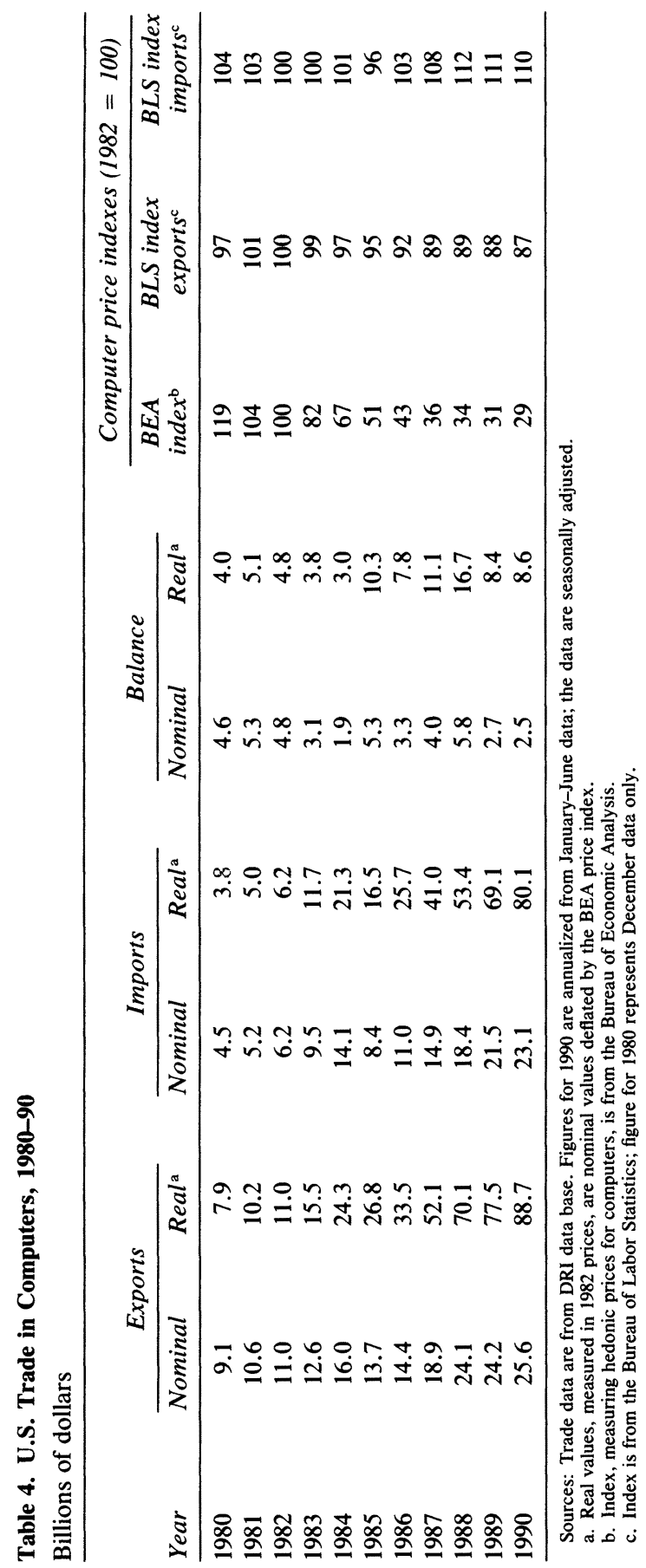


metric problems disappear. ${ }^{15}$ Indeed, Hooper and Mann found that the effect of the weaker dollar on import prices after 1985 matched historical experience.

Although better than implicit deflators, the BEA's fixed-weight price indexes are not entirely satisfactory for use in trade estimation. First, these fixed-weight price indexes use the same hedonic price series for export and import prices of computers. Even if we accept that the hedonic price measure is appropriate for computers used in the United States, it may not be appropriate for either exports or imports because the mix of products traded internationally is different. Recognizing this, the Bureau of Labor Statistics (BLS) has constructed price indexes for computer exports and imports that are based on conventional matchedmodel techniques. The BLS measures indicate a major divergence between export and import prices. Between 1982 and 1990, the nonhedonic BLS computer export prices fell by 13 percent, while nonhedonic computer import prices rose by 10 percent (see table 4). ${ }^{16}$

Second, even with appropriate price measures, when product mixes shift fixed-weight price measures cannot fully explain the behavior of trade volumes, nor can they be used to deflate trade values. ${ }^{17}$ Implicit deflators (or ideally chain-weighted deflators) would measure volume changes better. But when deflators are used as independent variables in a regression that explains trade volumes, they can bias the coefficients because any error in price measurement will create an offsetting error in volume measurement.

Although there is no clear solution to these problems, I address them by omitting computers from my regression analysis. I also generate my own price indexes for various import and export categories and for a broad measure of domestic prices with which to compare them. The end-use price series are formed by splicing the BLS end-use price series, which are available after mid-1983, with the BEA fixed-weight price indexes. The end-use price series and the fixed-weight deflators for exports and imports of services are aggregated using three-year moving

15. See Citrin (1989) and Hooper and Mann (1989).

16. For a more extensive discussion see Meade (forthcoming). The BEA follows a similar practice with aircraft. Both exports and imports are deflated by the same measure. See Parker and Bernstein (1990).

17. Indeed, the Federal Reserve Board model introduces a "bridging" equation that converts their prediction of trade prices into a forecast of the trade deflator for use in the equations that forecast trade volumes. 
Figure 1. U.S. Real Exchange Rate Indexes, 1980-90

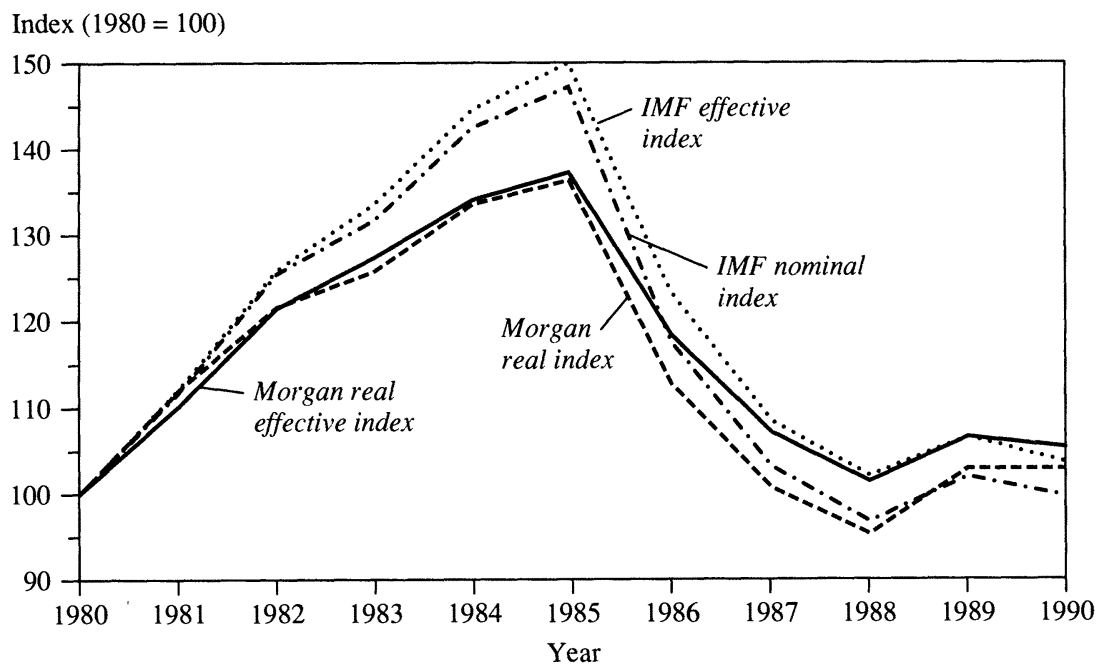

Source: IFS data base and J.P. Morgan's World Financial Markets, various editions. The base year, 1980, applies to all indexes. The IMF effective index is based on weights derived from the IMF's Multilateral Exchange Rate Model. The Morgan real index is an index of the real exchange rate measured against 15 other industrialized nations' currencies; the Morgan real effective index is measured against 18 industrialized and 22 less-developed nations' currencies.

averages of lagged end-use trade values for weights. To obtain a broad measure of domestic prices, each end-use category has been matched against a series in the producer price index (PPI). The PPI series have been aggregated using the same weights as the import price series. ${ }^{18}$ These price series represent an effort to account for compositional changes without introducing a major simultaneity bias into the price and volume measures. In what follows, the price series are referred to as "constructed" price indexes.

\section{Price Behavior}

Figure 1 shows changes in several widely used measures of the real effective exchange rate, and reveals that by the first half of 1990 the dollar had more or less returned to its 1980 level. If the trade balance

18. Unfortunately, the PPI is not reported by major end-use category. For example, the trade end-use category for capital goods excludes automotive products while they are included in the domestic series. 
Table 5. Alternative Price and Cost Indexes, Foreign and Domestic, 1980-90 Index $(1980=100)$

\begin{tabular}{|c|c|c|c|c|c|c|c|c|}
\hline \multirow[b]{2}{*}{ Year } & \multirow[b]{2}{*}{$\begin{array}{l}\text { Export } \\
\text { deflator }\end{array}$} & \multirow[b]{2}{*}{$\begin{array}{l}\text { Import } \\
\text { deflator }\end{array}$} & \multicolumn{3}{|c|}{ Constructed indexes ${ }^{\mathrm{a}}$} & \multirow{2}{*}{$\begin{array}{c}\text { Foreign } \\
\text { export } \\
\text { price } \\
\text { index }^{\mathrm{b}}\end{array}$} & \multirow{2}{*}{$\begin{array}{c}\text { Foreign } \\
\text { unit } \\
\text { labor } \\
\text { cost }^{\mathrm{b}}\end{array}$} & \multirow[b]{2}{*}{$P P I^{c}$} \\
\hline & & & $\begin{array}{l}\text { Export } \\
\text { prices }\end{array}$ & $\begin{array}{l}\text { Import } \\
\text { prices }\end{array}$ & $\begin{array}{c}\text { Domestic } \\
\text { prices }\end{array}$ & & & \\
\hline 1980 & 100.0 & 100.0 & 100.0 & 100.0 & 100.0 & 100.0 & 100.0 & 100.0 \\
\hline 1981 & 108.2 & 103.3 & 109.2 & 102.8 & 106.2 & 98.4 & 98.5 & 110.3 \\
\hline 1982 & 112.1 & 102.1 & 111.5 & 101.2 & 109.1 & 94.7 & 95.9 & 115.3 \\
\hline 1983 & 111.7 & 100.0 & 110.7 & 99.4 & 110.8 & 92.5 & 93.0 & 117.4 \\
\hline 1984 & 112.5 & 98.8 & 112.6 & 99.1 & 113.1 & 92.0 & 88.3 & 119.0 \\
\hline 1985 & 109.9 & 96.7 & 112.1 & 97.9 & 114.3 & 90.6 & 87.1 & 120.6 \\
\hline 1986 & 108.7 & 102.2 & 112.0 & 105.6 & 116.6 & 102.4 & 105.4 & 117.5 \\
\hline 1987 & 107.8 & 106.6 & 116.3 & 115.0 & 120.4 & 113.5 & 118.3 & 119.9 \\
\hline 1988 & 110.0 & 112.5 & 122.6 & 124.4 & 125.2 & 123.0 & 129.9 & 122.7 \\
\hline 1989 & 112.4 & 111.7 & 126.0 & 126.7 & 129.6 & 125.1 & 130.9 & 128.9 \\
\hline 1990 & 112.6 & 110.8 & 130.2 & 130.6 & 131.4 & 129.5 & 134.7 & 132.8 \\
\hline
\end{tabular}

Sources: DRI and OECD data bases, and author's own calculations. Figures for 1990 are annualized from JanuaryJune data. The price measures for exports are for nonagricultural, noncomputer goods and services. The price meașures for imports are for nonoil, noncomputer goods and services.

a. Price indexes are constructed by the author from BLS and BEA disaggregated price indexes as described in text.

b. Foreign values refer to all other OECD nations.

c. The PPI is the index for all nonagricultural finished goods, excluding food.

responds symmetrically to rises and falls in the exchange rate, we would expect that import and export prices would have returned to about their 1980 levels relative to domestic prices. This is precisely what has happened.

Table 5 indicates that when computers are excluded from the price calculations, the constructed export and import price series grow by 30 and 31 percent over the decade respectively. This is in contrast to the deflators for nonagricultural exports and nonoil imports, which increase only 13 and 11 percent. Thus, by the end of the 1980s, U.S. exporters had restored both their profit margins and their relative price competitiveness. The 30 percent rise in U.S. export prices matches the growth in the U.S. domestic price level (up 31 percent), the producer price index for finished goods excluding food (up 33 percent), and the OECD's manufactured export price index of U.S. competitors (up 30 percent). The rise in U.S. import prices matches the rise in domestic prices, foreign unit labor costs, and foreign export prices measured in dollars. Thus, by the late 1980 s, foreigners who had been competing in the U.S. market had lost a relative price advantage that had been associated with the strong dollar. As a result, the relative profitability of exporting to the 
Table 6. Ratio of Alternative Import Price Indexes to Domestic Price Index by End-Use Category, 1987-90

Ratio $(1980=100)$

\begin{tabular}{|c|c|c|c|c|c|}
\hline \multirow[b]{2}{*}{ Category } & \multirow{2}{*}{$\begin{array}{l}\text { Import price } \\
\text { measure }\end{array}$} & \multicolumn{4}{|c|}{ Year } \\
\hline & & 1987 & 1988 & 1989 & 1990 \\
\hline \multicolumn{6}{|l|}{ Total imports } \\
\hline \multirow[t]{3}{*}{ Goods and services, nonoil } & implicit & 86 & 87 & 84 & 82 \\
\hline & fixed-weight & 91 & 94 & 93 & 92 \\
\hline & constructed & 93 & 96 & 95 & 95 \\
\hline \multirow[t]{3}{*}{ NONC goods and services ${ }^{\mathrm{a}}$} & implicit & 93 & 97 & 96 & 96 \\
\hline & fixed-weight & 93 & 97 & 96 & 95 \\
\hline & constructed & 96 & 99 & 98 & 98 \\
\hline \multicolumn{6}{|l|}{ End-use category } \\
\hline \multirow[t]{3}{*}{ Capital goods } & implicit & 68 & 67 & 63 & 59 \\
\hline & fixed-weight & 89 & 92 & 90 & 90 \\
\hline & constructed & 92 & 95 & 93 & 93 \\
\hline \multirow[t]{3}{*}{ Capital goods, noncomputer } & implicit & 96 & 101 & 102 & 103 \\
\hline & fixed-weight & 104 & 108 & 107 & 106 \\
\hline & constructed & 96 & 100 & 98 & 99 \\
\hline \multirow[t]{3}{*}{ Food } & implicit & 97 & 94 & 86 & 87 \\
\hline & fixed-weight & 97 & 94 & 86 & 87 \\
\hline & constructed & 101 & 96 & 89 & 90 \\
\hline \multirow[t]{3}{*}{ Nonoil industrial supplies } & implicit & 73 & 79 & 79 & 78 \\
\hline & fixed-weight & 73 & 79 & 79 & 78 \\
\hline & constructed & 79 & 84 & 82 & 80 \\
\hline \multirow[t]{3}{*}{ Autos } & implicit & 112 & 116 & 117 & 117 \\
\hline & fixed-weight & 112 & 116 & 117 & 117 \\
\hline & constructed & 114 & 119 & 120 & 120 \\
\hline \multirow[t]{3}{*}{ Consumer goods } & implicit & 90 & 92 & 90 & 90 \\
\hline & fixed-weight & 90 & 92 & 90 & 90 \\
\hline & constructed & 92 & 94 & 93 & 93 \\
\hline
\end{tabular}

Source: Author's own calculations using OECD and DRI data bases. Constructed import and domestic price indexes are calculated by the author as described in the text. Figures for 1990 are annualized from January-June data; the data are seasonally adjusted. Import price measures are the implicit deflator, the fixed-weight deflator, and the author's constructed index.

a. NONC represents nonoil and noncomputer imports.

United States, compared with other destinations, returned to its 1980 level.

Table 6illustrates the difference that alternative import price measures make on various categories of imports. The table gives ratios of selected import price indexes to the constructed domestic price index. For aggregate nonoil imports, the relative prices in 1990 are 18 percent lower 
than their 1980 levels when implicit deflators are used and only 8 percent lower when using the fixed-weight index, which includes the hedonic price series for computers. By giving computers a smaller weight, the fixed-weight measure eliminates most, but not all, of the relative weakness in import price growth. The constructed import price index, which uses the (nonhedonic) BLS series rather than the (hedonic) BEA computer price series, shows relative import prices just 5 percent below their 1980 level. With computers excluded from the aggregate-as in several end-use categories in table 6-all three price indexes show that 1990 relative import prices are near their 1980 levels. These measures also show that, like the real exchange rate, relative import prices have remained in a narrow range in 1988, 1989, and the first half of 1990. Table 6 also reports on the differences among alternative price measures in individual end-use categories. In every end-use category except "capital goods, noncomputer," the constructed price series rises more over the decade than either the deflator or fixed-weight price series. ${ }^{19}$

The relative price of automobile imports deserves special notice. Jagdish Bhagwati argues that the voluntary export restraint (VER) arrangements, which have regulated the imports of Japanese autos, should have led to higher prices in the early 1980s. As long as the VERs were binding, there should have been no further price increases when the dollar declined. Thus, Bhagwati suggests that VER quotas would inhibit adjustment to the lower dollar. ${ }^{20}$ The evidence, however, suggests that while he may have been correct in theory, in practice he was not. Between 1980 and 1985, relative auto-import prices were actually unchanged, but between 1985 and the first half of 1990 they increased by 20 percent.

\section{Explaining Import and Export Prices}

Table 7 reports the results of regressions that explain the constructed indexes of export and import prices. The export price equations regress nonagricultural, noncomputer export prices on a constant, the U.S. PPI for finished goods excluding food, and foreign export prices. ${ }^{21}$ The equations perform well. Fitted to data from 1976 and 1984, the equation

19. For a more extensive discussion see Alterman (forthcoming).

20. Bhagwati (1988).

21. Foreign export prices are expressed in U.S. dollars, as measured by the OECD. 
tracks export prices out of sample accurately. The prediction errors over the eleven semiannual, out-of-sample observations have a mean absolute error of 0.5 percent. In the first half of 1990 , the equation predicts the level of export prices with an error of just 0.3 percent. It suggests nothing unusual about the pricing of U.S. exports in the second half of the 1980s. Over time, taking foreign prices as given, each 1 percent appreciation (depreciation) in the dollar exchange rate lowers (raises) U.S. export prices measured in dollars by 0.24 percent.

The import price equations in table 7 explain U.S. nonoil, noncomputer (NONC) import prices as a function of foreign export prices and U.S. domestic prices. The equations suggest that after about a year, 70 percent of the change in foreign prices is passed through into U.S. import prices. Although the residuals of the equations are autocorrelated, the coefficients change little whether or not the equation is corrected for autocorrelation. In table 7, as in all subsequent tables, the appearance of a rho summary statistic indicates that the equation was corrected for autocorrelation.

The regression has small standard errors within sample. And when fitted between 1976 and 1984, it tracks well out of sample with a mean absolute error of just 1.7 percent, without systematic over- or underprediction. It underpredicts NONC import prices in the first half of 1990 by just 2.3 percent. ${ }^{22}$

\section{Explaining Import and Export Volumes}

I now turn to explaining trade flows, both by estimating equations for trade volumes and, as an alternative, for import values. All the equations have been estimated using semiannual data from 1976 to the first half of 1990. The sample period is determined by the availability of computer price data. All variables are specified in logarithms so that the coefficients may be interpreted as elasticities.

IMPORTS. In equations 8.1 and 8.2 in table 8 , the quantity of NONC imports of goods and services is explained as a function of real GNP, potential GDP, and distributed-lagged values of the ratio of nonoil import prices to U.S. producer prices. The coefficients on relative prices are estimated using a second-order Almon lag specification.

22. This result contrasts with Meade, who finds that, despite exclusion of computer prices, prices tend to be overpredicted. She speculates that there are problems in the specification of the Hooper-Helkie model, which uses consumer prices. 


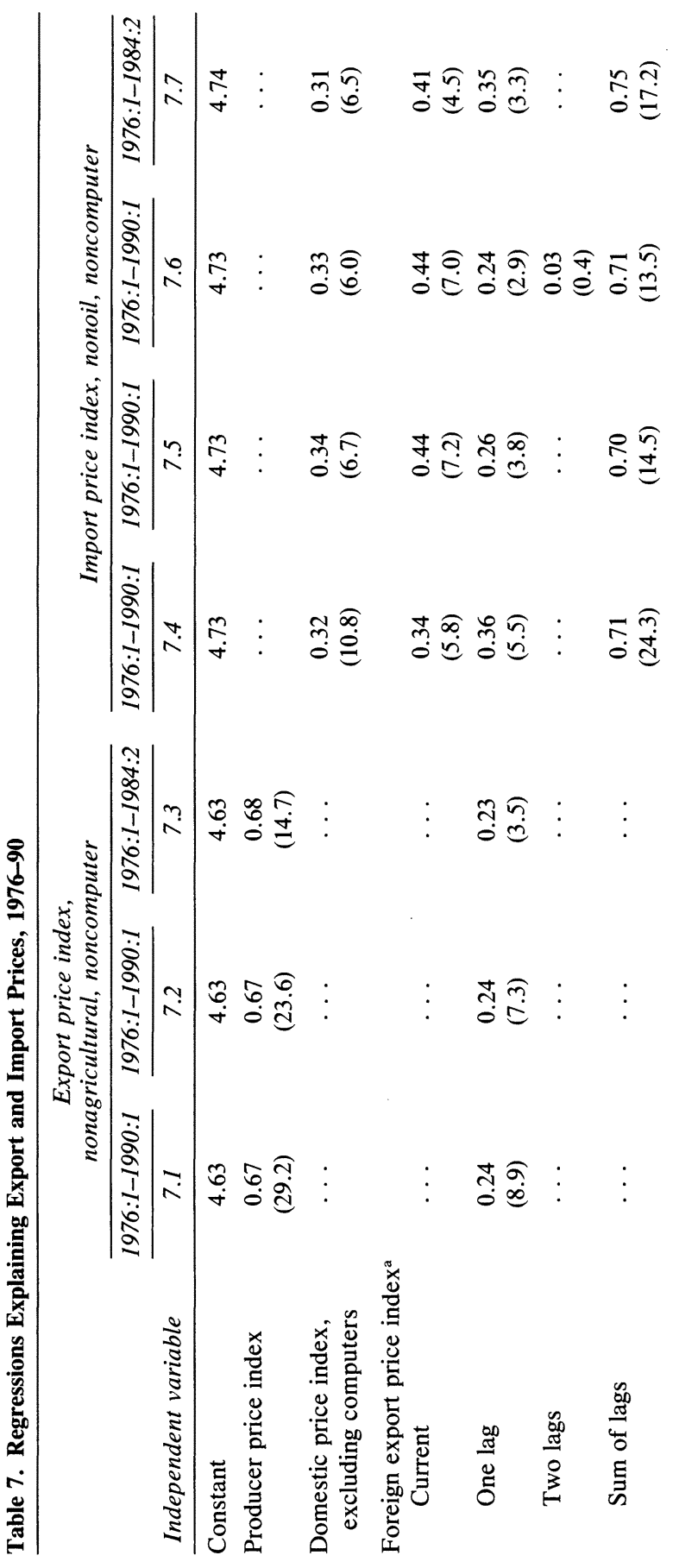




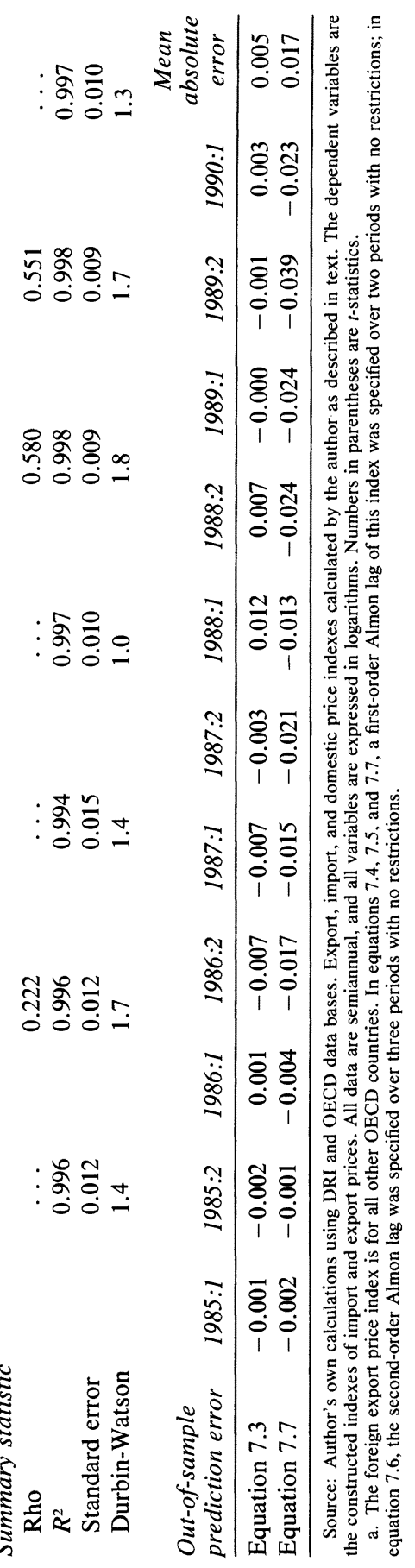


Table 8. Regressions Explaining Nonoil, Noncomputer Import Volumes, 1976-90

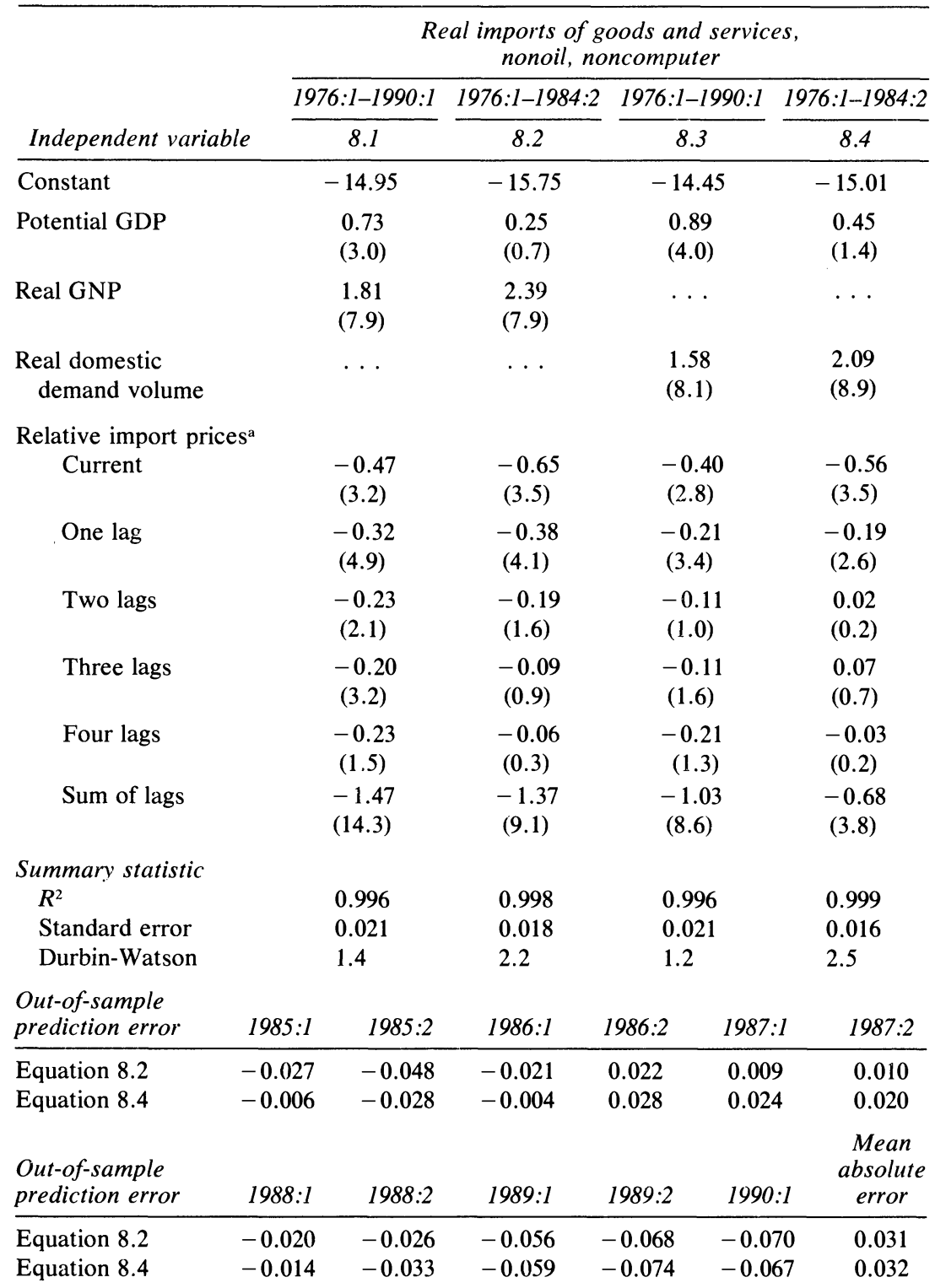

Source: Author's own calculations using DRI and OECD data bases. The base year, 1982, applies to all real values. All data are semiannual; all variables are expressed in logarithms. Numbers in parentheses are $t$-statistics.

a. Relative import price figures, excluding oil and computer trade, are the ratio of the author's own import and domestic price indexes. A second-order Almon lag of relative import prices was specified over five periods with no restrictions. 
Equation 8.1, fitted over the entire sample period, indicates that over the long run, when actual and potential output grow at the same rate, each 1 percent increase in output will be associated with a 2.5 percent increase in the volume of NONC imports, the sum of the coefficients on actual and potential output. For each percentage point deviation from this path, imports will deviate by 1.8 percent in the same direction. The price effects, for their part, generate a $J$ curve in the short run. In the first year, a 1 percent increase in relative import prices will reduce volumes by only 0.8 percent. After eighteen months, however, the volume reductions will outweigh the price increases. Over the long run (two and a half years), import volumes will decline by 1.5 percent. The equation tracks import volumes within sample with a standard error of just 2.1 percent. However, there is serial autocorrelation in the error term.

In equation 8.2, fitted over the subsample 1976-84, the estimates of the cyclical effects are somewhat larger. Each 1 percent deviation of real GNP from its potential is associated with a 2.4 percent deviation of imports in the same direction. However, the estimate of the long-run impact of growth is virtually unchanged. When actual and potential output grow at the same rate, each 1 percent increase in output is associated with a 2.6 percent increase in import volumes. The estimate of the price elasticity over the long run is slightly lower than it was for the full sample equation. But the equation puts more of the price effects in the first and second periods.

When equation 8.2 is used to forecast out of sample, it has a mean absolute error of 3.1 percent from 1985 to the first half of 1990. The equation tracks imports accurately through the second half of 1988 , when the overprediction is just 2.6 percent. In 1989 and the first half of 1990 , however, the equation overpredicts import volumes by an average of 6.5 percent. The negative errors, or overpredictions, certainly contradict the pessimists who have claimed hysteresis would reduce the responsiveness of import volumes to relative price changes. To some extent, the results support the optimists who believe that the U.S. import growth coefficients might be slowing.

The last two equations in table 8 report an alternative specification in which the volume of real domestic demand-the sum of real consumption, real investment, and real government expenditures-is used as the short-run activity variable. This specification yields lower estimates for 
the price elasticities but similar long-run income elasticities. It indicates even more strongly that import volumes have been unexpectedly low since the second half of 1988 .

IMPORTS: A NOMINAL SPECIFICATION. Thus far I have presented equations both for an import price index that does not correspond to the import price deflator and for an import quantity that has been estimated using the official nonoil, noncomputer import deflator. Although instructive, the product of the price and quantity forecasts from these equations does not equal the nominal value of imports. To obtain a complete system capable of forecasting nominal trade values from these equations would require forecasting the implicit deflator. As an alternative, table 9 presents equations explaining nominal imports directly.

The first pair of equations, 9.1 and 9.2, explains nominal, nonoil imports of goods and services as a function of nominal GNP and relative import prices. Computers are included here; import prices for computers use the BLS measure. The equation works well and has a standard error of 2.4 percent over the period 1976-90. The implied relative price elasticity is -0.4 , and the coefficients indicate a $J$-curve effect in which higher relative import prices raise the value of imports in the first year, then more than offset this effect over the following eighteen months. Fitted between 1976 and 1984, the equation tracks import values out of sample with remarkable accuracy. In the first half of 1990, the error is just 0.2 percent, demonstrating the predictability and structural stability of the import equation.

An alternative specification, shown in equations 9.3 and 9.4, explains nominal, nonoil merchandise imports as a function of nominal goods output. Again the performance is extremely satisfactory. In the first half of 1990 , the out-of-sample error is 0.1 percent. Thus, all told there is some evidence that import volumes are weak, but it is hard to argue that U.S. nonoil import values are way off track. ${ }^{23}$

EXPORTS. To explain nonagricultural, noncomputer (NANC) export volumes, I use domestic demand in the rest of the world (basically other OECD countries) weighted by its 1980 share in U.S. exports. Relative export prices are defined as the distributed lagged values of the ratio of U.S. nonagricultural export prices-formed by weighted averages of nonagricultural end-use price series-to foreign manufactured-goods

23. For a more rigorous evaluation of the accuracy of trade equation forecasting systems see Marquez and Ericsson (1990). 
Table 9. Regressions Explaining Nominal, Nonoil Import Volumes, 1976-90

\begin{tabular}{|c|c|c|c|c|c|c|}
\hline \multirow[b]{2}{*}{ Independent variabl } & & \multicolumn{2}{|c|}{$\begin{array}{l}\text { Nonoil imports of } \\
\text { goods and services }\end{array}$} & \multicolumn{3}{|c|}{$\begin{array}{l}\text { Nonoil merchandise } \\
\text { imports }\end{array}$} \\
\hline & & $\begin{array}{l}976: 1-1990: 1 \\
9.1\end{array}$ & $\begin{array}{c}1976: 1-1984: 2 \\
9.2\end{array}$ & $\begin{array}{r}1976: 1- \\
9\end{array}$ & $990: 1 \quad 19$ & $\begin{array}{c}1976: 1-1984: 2 \\
9.4\end{array}$ \\
\hline \multicolumn{2}{|l|}{ Constant } & -4.22 & -3.09 & -3. & & -3.08 \\
\hline \multicolumn{2}{|l|}{ GNP } & $\begin{array}{c}1.43 \\
(106.7)\end{array}$ & $\begin{array}{c}1.45 \\
(38.4)\end{array}$ & . & & $\ldots$ \\
\hline \multicolumn{2}{|l|}{ Goods output } & $\ldots$ & $\ldots$ & $\begin{array}{r}1.6 \\
(114\end{array}$ & & $\begin{array}{c}1.66 \\
(44.1)\end{array}$ \\
\hline \multicolumn{7}{|c|}{ Relative import prices ${ }^{\mathrm{a}}$} \\
\hline \multicolumn{2}{|l|}{ Current } & $\begin{array}{l}0.53 \\
(3.3)\end{array}$ & $\begin{array}{l}0.53 \\
(2.4)\end{array}$ & $\begin{array}{l}0.6 \\
(4 .\end{array}$ & & $\begin{array}{l}0.59 \\
(2.9)\end{array}$ \\
\hline \multicolumn{2}{|l|}{ One lag } & $\begin{array}{l}0.12 \\
(1.8)\end{array}$ & $\begin{array}{l}0.09 \\
(0.9)\end{array}$ & $\begin{array}{l}-0 . \\
(0 .\end{array}$ & & $\begin{array}{l}-0.11 \\
(1.2)\end{array}$ \\
\hline \multicolumn{2}{|l|}{ Two lags } & $\begin{array}{l}-0.18 \\
(1.4)\end{array}$ & $\begin{array}{l}-0.24 \\
(1.4)\end{array}$ & $\begin{array}{c}-0 . \\
(3 .\end{array}$ & & $\begin{array}{l}-0.48 \\
(3.0)\end{array}$ \\
\hline \multicolumn{2}{|l|}{ Three lags } & $\begin{array}{l}-0.38 \\
(5.6)\end{array}$ & $\begin{array}{l}-0.46 \\
(4.1)\end{array}$ & $\begin{array}{l}-0 . \\
(8 .\end{array}$ & & $\begin{array}{l}-0.53 \\
(5.1)\end{array}$ \\
\hline \multicolumn{2}{|l|}{ Four lags } & $\begin{array}{l}-0.47 \\
(3.0)\end{array}$ & $\begin{array}{l}-0.58 \\
(2.3)\end{array}$ & $\begin{array}{l}-0 . \\
(2 .\end{array}$ & & $\begin{array}{l}-0.25 \\
(1.1)\end{array}$ \\
\hline \multicolumn{2}{|l|}{ Sum of lags } & $\begin{array}{l}-0.38 \\
(3.2)\end{array}$ & $\begin{array}{l}-0.67 \\
(3.0)\end{array}$ & $\begin{array}{l}-0 . \\
(5 .\end{array}$ & & $\begin{array}{l}-0.79 \\
(3.9)\end{array}$ \\
\hline \multicolumn{7}{|l|}{ Summary statistic } \\
\hline$R^{2}$ & & 0.998 & 0.997 & 0.9 & & 0.997 \\
\hline Standard error & & 0.024 & 0.028 & 0.0 & & 0.026 \\
\hline Durbin-Watson & & 1.7 & 1.9 & 2.2 & & 2.5 \\
\hline $\begin{array}{l}\text { Out-of-sample } \\
\text { prediction error }\end{array}$ & 1985:1 & $1985: 2$ & 1986:1 & $1986: 2$ & 1987:1 & 1987:2 \\
\hline Equation 9.2 & -0.033 & -0.045 & -0.032 & 0.007 & -0.008 & 0.006 \\
\hline Equation 9.4 & -0.036 & -0.056 & -0.036 & -0.034 & -0.060 & -0.035 \\
\hline $\begin{array}{l}\text { Out-of-sample } \\
\text { prediction error }\end{array}$ & 1988:1 & 1988:2 & 1989:1 & 1989:2 & 1990:1 & $\begin{array}{l}\text { Mean } \\
\text { absolute } \\
\text { error }\end{array}$ \\
\hline Equation 9.2 & 0.008 & 0.032 & 0.012 & 0.024 & 0.002 & 0.027 \\
\hline Equation 9.4 & -0.029 & -0.005 & -0.000 & 0.007 & 0.001 & 0.019 \\
\hline
\end{tabular}

Source: Author's own calculations using DRI data base. All data are semiannual; all variables are expressed in logarithms. Numbers in parentheses are $t$-statistics.

a. Relative import price figures, excluding oil and computer trade, are the ratio of the author's own import and domestic price indexes. A second-order Almon lag of relative import prices was specified over five periods with no restrictions. 
export prices as measured by the OECD. The price coefficient is estimated using a third-order Almon-lag specification over six periods. Again, estimates are reported for the span 1976-90, and for 1976-84. This specification performed better than, but similarly to, ones that use a gap measure for the rest of the world or some measure of U.S. export market growth.

Equation 10.1 in table 10 tracks NANC export volumes with a standard error of 2.1 percent. Each 1 percent increase in foreign demand raises U.S. NANC exports by 1.6 percent. The long-run price elasticity on U.S. exports is 1.1 , with the effects spread out fairly evenly over the full three-year period. Estimates using lags longer than three years, which are not reported in the table, do not add to the equation's explanatory power.

The coefficients remain fairly stable when the specification is estimated without correction for first-order serial autocorrelation (equation 10.2), and over the subsample period 1976-84 (equation 10.3). When estimated over the subsample, the equation tracks exports out of sample with considerable accuracy. The mean absolute error of the elevenperiod forecast is 2.7 percent, which compares quite favorably with the in-sample standard error of 1.9 percent. The larger errors in the out-ofsample forecast occur between the first halves of 1986 and 1987, when U.S. export volumes were higher than predicted. Thereafter the equation tracks NANC volumes well; in the first half of 1990 , it indicates that they were just 1.3 percent higher than might have been expected. Taken together with the price forecast from equation 7.3, which indicates export prices were just 0.3 percent higher than expected, this system has no trouble explaining export behavior.

\section{Interpretation of Empirical Results}

The coefficients on the GNP terms in import equations like these could be interpreted as pure income elasticities under the assumption of both imperfect substitution and infinite supply elasticities of importable goods both at home and abroad. But, as has long been recognized, it is likely that, given their relatively crude formulation, these "activity" effects capture not only pure income effects, but also the impact of supply-side effects and nonprice influences. Nonprice influences, such as product quality, variety, and innovation, affect trade flows in a fairly 
Table 10. Regressions Explaining Nonagricultural, Noncomputer Export Volumes, 1976-90

\begin{tabular}{|c|c|c|c|c|c|c|}
\hline & & $\begin{array}{r}\text { Real } \\
n\end{array}$ & $\begin{array}{l}\text { al expor } \\
\text { nonagri }\end{array}$ & $\begin{array}{l}\text { ts of goods ano } \\
\text { cultural, nonco }\end{array}$ & $\begin{array}{l}\text { servic } \\
\text { mputer }\end{array}$ & $\begin{array}{l}\text { ces } \\
r\end{array}$ \\
\hline & & $1976: 1-1990: 1$ & & 1976:1-1990:1 & & $1976: 1-1984: 2$ \\
\hline Independent vari & & 10.1 & & 10.2 & & 10.3 \\
\hline Constant & & 2.93 & & 2.90 & & 3.45 \\
\hline Foreign demand vo & Ime & $\begin{array}{c}1.60 \\
(33.7)\end{array}$ & & $\begin{array}{c}1.60 \\
(40.5)\end{array}$ & & $\begin{array}{c}1.58 \\
(12.8)\end{array}$ \\
\hline Relative export pri & & & & & & \\
\hline Current & & $\begin{array}{l}-0.32 \\
(2.7)\end{array}$ & & $\begin{array}{l}-0.30 \\
(2.7)\end{array}$ & & $\begin{array}{l}-0.21 \\
(1.2)\end{array}$ \\
\hline One lag & & $\begin{array}{l}-0.04 \\
(0.4)\end{array}$ & & $\begin{array}{l}-0.05 \\
(0.5)\end{array}$ & & $\begin{array}{l}-0.02 \\
(0.1)\end{array}$ \\
\hline Two lags & & $\begin{array}{l}-0.08 \\
(1.0)\end{array}$ & & $\begin{array}{l}-0.09 \\
(1.1)\end{array}$ & & $\begin{array}{l}-0.15 \\
(1.4)\end{array}$ \\
\hline Three lags & & $\begin{array}{l}-0.22 \\
(2.8)\end{array}$ & & $\begin{array}{l}-0.22 \\
(2.8)\end{array}$ & & $\begin{array}{l}-0.36 \\
(3.4)\end{array}$ \\
\hline Four lags & & $\begin{array}{l}-0.29 \\
(3.0)\end{array}$ & & $\begin{array}{l}-0.29 \\
(0.3)\end{array}$ & & $\begin{array}{l}-0.40 \\
(3.3)\end{array}$ \\
\hline Five lags & & $\begin{array}{l}-0.09 \\
(0.7)\end{array}$ & & $\begin{array}{l}-0.09 \\
(0.7)\end{array}$ & & $\begin{array}{l}0.00 \\
(0.0)\end{array}$ \\
\hline Sum of lags & & $\begin{array}{l}-1.05 \\
(12.2)\end{array}$ & & $\begin{array}{l}-1.04 \\
(14.5)\end{array}$ & & $\begin{array}{r}-1.13 \\
(8.5)\end{array}$ \\
\hline Summary statistic & & & & & & \\
\hline Rho & & 0.243 & & & & \\
\hline$R^{2}$ & & 0.989 & & 0.989 & & 0.991 \\
\hline Standard error & & 0.021 & & 0.021 & & 0.019 \\
\hline Durbin-Watson & & 2.0 & & 1.5 & & 1.7 \\
\hline $\begin{array}{l}\text { Out-of-sample } \\
\text { prediction error }\end{array}$ & $1985: 1$ & $1985: 2$ & 1986:1 & 1986:2 & 1987:1 & 1987:2 \\
\hline Equation 10.3 & 0.036 & -0.006 & 0.059 & 0.074 & 0.054 & 0.011 \\
\hline $\begin{array}{l}\text { Out-of-sample } \\
\text { prediction error }\end{array}$ & 1988:1 & 1988:2 & 1989:1 & 1989:2 & 1990:1 & $\begin{array}{c}\text { Mean } \\
\text { absolute } \\
\text { error }\end{array}$ \\
\hline Equation 10.3 & 0.014 & -0.024 & 0.004 & -0.007 & 0.013 & 0.027 \\
\hline
\end{tabular}

Source: Author's own calculations using DRI and OECD data bases. All data are semiannual; all variables are expressed in logarithms. Numbers in parentheses are $t$-statistics.

a. Relative export prices are defined as the ratio of the author's own nonagricultural, noncomputer export price index and the foreign export price index for all other OECD countries. A third-order Almon lag of relative export prices was specified over six periods with no restrictions. 
steady fashion; they are, therefore, difficult to separate out from pure income effects. ${ }^{24}$ Because these equations fail to provide an adequate structural description of import determination, they are not well suited for projecting the effects of growth. Efforts must be made to capture supply-side effects more explicitly and successfully than the equations do. ${ }^{25}$ Accordingly, the equations should be viewed as statistical summaries of the relationship between endogenous variables, rather than as strict structural models of income effects. ${ }^{26}$ Nonetheless, the differences in elasticity do help detect the role of long-run declines in U.S. competitiveness, and help forecast under the assumption that the relationships between these variables continue to hold. ${ }^{27}$

Consider the NANC export equation 10.2 together with the NONC import equation 8.1. The comparison reveals the long established Houthakker-Magee effect that similar rates of long-run growth in the United States and the rest of the world are associated with a declining trade balance or continuous real dollar depreciation. ${ }^{28}$ Over the long run, my regression equations suggest that the activity elasticity of U.S. exports is 1.6 while the activity elasticity of U.S. imports is 2.5 . Thus, with unchanged relative prices, rates of growth in the United States that are about 60 percent of those abroad are required to keep exports and imports growing at similar rates. Surprisingly, perhaps, the coefficients on the demand variables in equations 8.3 and 10.1 indicate that the effects on trade of cyclical changes in the United States and the rest of the world are quite similar. ${ }^{29}$

OVERALL FORECASTS. Taken as a system, the equations fitted over the period 1976-84 forecast the behavior of the U.S. nonoil, nonagricultural, noncomputer (NONANC) trade balance over the rest of the decade fairly accurately. When the forecasts of the price (equations 7.3 and 7.7) and volume (equations 8.2 and 10.3) are combined with the actual values for the independent variables and U.S. import and export deflators, the

24. See Goldstein and Khan (1985).

25. Meade (forthcoming) reports that the proxy used by Hooper and Helkie to capture these effects, relative capacity growth in the United States and the rest of world, is no longer significant when computers are dropped from the regressions.

26. Krugman (1989b) gives a theoretical explanation for an inverse relationship between import elasticities and growth rates.

27. For a more complete discussion see Lawrence (1988).

28. Houthakker and Magee (1969).

29. Similar results are obtained by Marquez (1988). 
result is a forecast of the nominal NONANC balance of $\$ 82.1$ billion in the first half of 1990 compared with the actual value of $\$ 51.8$ billion. The forecast of NANC exports is remarkably accurate-the predicted value of $\$ 459.3$ billion matches the actual value of $\$ 459.2$ billion. All the error in forecasting the 1990 trade balance comes from the overprediction of NONC imports: the predicted value of $\$ 541.5$ billion exceeded the actual value of $\$ 511.0$ billion.

ALTERnATIVE GROWTH PATHs. In a 1988 study, Ralph Bryant uses five major econometric models to construct a base-case projection for the current account through $1991 .{ }^{30}$ His projection forecasts a current account deficit of $\$ 108$ billion in 1989 and $\$ 113$ billion in 1990. The projection was based on the assumption that after 1987, annual real growth in the United States and Europe would average 3.0 percent, while Japanese growth would average 3.5 percent. In fact, between 1987 and 1989 annual growth in Europe and Japan averaged 3.5 percent and 5.2 percent respectively. The United States, on the other hand, grew by only 2.6 percent annually.

When equations 8.1 and 10.2 are used to forecast trade using the growth rates assumed in the Bryant simulations and the actual values for relative prices and import and export deflators, they predict a NONANC deficit of $\$ 99.5$ billion for the first half of 1990 compared with the $\$ 68.9$ billion forecast when the equations use actual growth rates in the United States and the rest of the world. Thus, the differences between projected and actual growth rates can explain $\$ 30.5$ billion in smaller deficits. This is sufficient to account for the difference between the actual current account deficit of $\$ 79.3$ billion in the first half of 1990 and the forecast in the Bryant base case.

\section{Trade Performance in the 1980 s}

Over the decade as a whole, the growth in real GNP in the United States was somewhat lower than the growth in real GDP abroad: 30.4 percent in the United States compared with 34.9 percent abroad. In addition, at the end of the decade, relative U.S. export and import prices were roughly back to their 1980 levels, and have remained fairly constant over the past three years. Thus, it is clear, in an approximate sense, that the Houthakker-Magee effect is confirmed. With relative prices basically

30. Bryant (1988). 
the same in 1990 as they were in 1980 and with somewhat slower growth rates at home than abroad, the U.S. NONANC trade balance declined over the decade by $\$ 75.2$ billion. Measured logarithmically, the coverage ratio (the ratio of nominal exports to nominal imports) declined by 19.5 percent. In one sense, this decline measures the loss of U.S. competitiveness over the decade. A rough calculation suggests that restoring the NONA coverage ratio to its 1980 level would have required a depreciation of roughly 13 percent over the past three years. Such a depreciation would have reduced the NONANC deficit by $\$ 96$ billion. Even if one ignores the boost to agricultural exports and direct foreign investment, the improvement would have been sufficient to balance the U.S. current account in the first half of $1990 .{ }^{31}$ Of course, there is nothing necessarily optimal about the 1980 coverage ratio. In 1990 , the ratio implies a nominal NONANC balance of about $\$ 40$ billion, compared with a nominal balance of $\$ 19$ billion in 1980 . To restore the nominal NONA balance to $\$ 19$ billion, a devaluation of only 10 percent would have been needed. Prior to the recent invasion of Kuwait, the trade balance in agricultural exports and oil imports had improved by $\$ 14$ billion over the decade. Restoring the trade balance in goods and services to its 1980 nominal level would, therefore, have required a devaluation of only 8.0 percent.

Regression equations 8.1 and 10.2 can be used to decompose the NONANC coverage ratio. To begin, the value of exports, $V_{x}$, is determined by the price and quantity of exports. The same holds true for the value of imports, $V_{m}$. Thus, $V_{x}=P_{x} Q_{x}$ and $V_{m}=P_{m} Q_{m}$, where $P$ denotes price and $Q$ the quantity of exports $(x)$ and imports $(m)$. Further,

$$
\ln V_{x}-\ln V_{m}=\ln P_{x}-\ln P_{m}+\ln Q_{x}-\ln Q_{m} .
$$

As specified, regression equation 10.2 for NANC goods and services indicates that

$$
\ln Q_{x}=a_{1} \ln F D V-a_{2} \ln P_{x}^{*}+e_{x}
$$

31. The equation system above indicates that a 1 percent depreciation of the dollar would lower relative U.S. export prices by 0.7 percent and raise export prices in U.S. dollars by 0.3 percent. Thus, using the export price elasticity of 1.05 , each 1 percent depreciation would raise export values by 1.04 percent. Devaluation would raise import prices by 0.7 percent and, given an elasticity of 1.47 , lower quantities by 1.03 thus reducing import values by 0.33 percent. Scaled by the first half of 1990 values, each 1 percent decline in the dollar reduces the NONANC trade deficit by $\$ 7.2$ billion. 
where $F D V$ is the foreign demand volume, $P_{x}^{*}$ represents relative NANC export prices, and $e_{x}$ is the residual. Similarly regression equation 8.1 for NONC goods and services indicates that

$$
\ln Q_{m}=a_{3} \ln G N P_{82}+a_{4} \ln G D P_{p o t}-a_{5} \ln P_{m}^{*}+e_{m},
$$

where $G N P_{82}$ and $G D P_{p o t}$ represent real and potential output respectively, $P_{m}^{*}$ represents relative NONC import prices, and $e_{x}$ is the residual. Equations 2 and 3 can be substituted into equation 1 to yield

$$
\begin{gathered}
\ln V_{x}-\ln V_{m}=a_{1} \ln F D V-a_{3} \ln G N P_{82}-a_{4} \ln G D P_{p o t} \\
\quad(\text { activity effect) } \\
-a_{2} \ln P_{x}^{*}+a_{5} \ln P_{m}^{*} \\
\quad(\text { price effect }) \\
+\ln P_{x}-\ln P_{m} \\
\quad(\text { terms of trade effect }) \\
+e_{x}-e_{m} \\
\text { (residual) }
\end{gathered}
$$

The results of such a decomposition are given in table 11, which reports changes in the NONANC coverage ratio over the 1980s. During this period, the equation system accurately tracks U.S. trade performance, and confirms that price effects have no impact on the coverage ratio over this period. The terms of trade effects are relatively small and positive for the decade as a whole ( 2.0 percent), and are partially offset by a small residual of -0.6 percent. The dominant impact, therefore, comes from the activity effects. These account for almost the entire 21.5 percent logarithmic decline in the coverage ratio.

The decomposition exercise also offers some interesting insights into the fluctuations in the coverage ratio over the decade. Between 1980 and 1985 , the large decline in the coverage ratio reflects the effect of faster growth in the United States and the impact of the strong dollar, which was partially offset by improvements in the U.S. terms of trade. Typically, as the price equations indicate, with a dollar appreciation import prices, expressed in dollars, tend to fall and export prices to rise. In the second half of the decade, relatively slower growth in the United States has offset most of the differential in activity elasticities, so that 
Table 11. Decomposition of Imports and Exports by Price and Quantity, 1980-90 Percent

\begin{tabular}{lrrrrr}
\hline & \multicolumn{5}{c}{ Total change } \\
\cline { 2 - 6 } & $1980-90$ & $1980-85$ & $1985-90$ & $1985-87$ & $1987-90$ \\
\hline Imports & & & & & \\
Value & 95.0 & 50.9 & 44.0 & 26.0 & 18.0 \\
Deflator & 26.2 & -0.8 & 27.1 & 14.8 & 12.3 \\
Quantity & 68.7 & 51.8 & 16.9 & 11.2 & 5.7 \\
$\quad$ Price & -2.1 & 17.8 & -19.9 & -7.1 & -12.9 \\
Income & 71.7 & 34.6 & 37.1 & 16.0 & 21.1 \\
Error & -0.9 & -0.7 & -0.3 & 2.3 & -2.6 \\
Exports & & & & & \\
Value & 73.4 & 6.5 & 66.9 & 24.5 & 42.4 \\
Deflator & 28.2 & 15.0 & 13.2 & 3.6 & 9.6 \\
Quantity & 45.2 & -8.6 & 53.8 & 20.9 & 32.9 \\
$\quad$ Price & -2.0 & -22.1 & 20.1 & 7.7 & 12.3 \\
Income & 48.7 & 15.5 & 33.2 & 13.4 & 19.8 \\
Error & -1.6 & -2.0 & 0.5 & -0.3 & 0.8 \\
Balance & & & & & \\
Value & -21.5 & -44.5 & 22.9 & -1.5 & 24.4 \\
Terms of trade & 2.0 & 15.9 & -13.9 & -11.2 & -2.8 \\
Quantity & -23.5 & -60.4 & 36.9 & 9.7 & 27.2 \\
$\quad$ Price & 0.1 & -39.9 & 40.0 & 14.7 & 25.2 \\
Income & -23.0 & -19.1 & -3.9 & -2.5 & -1.4 \\
Error & -0.6 & -1.4 & -0.8 & -2.6 & -3.4 \\
\hline
\end{tabular}

Source: Author's own calculations using DRI data base. The price and income decompositions of the changes in quantity are generated with equations $1-4$ in the text and with regression equations 10.2 , for exports, and 8.1 , for imports. Percent changes are derived from differences in logarithms from beginning to end of period. Figures for 1990 are annualized from January-June data; the data are seasonally adjusted.

the decline in the dollar has been associated with a near complete reversal in the effects of both negative relative prices and positive terms of trade from the first half of the decade.

The dollar's decline after 1985 has operated in two distinct phases. Between 1985 and 1987, the nominal coverage ratio changed little because the negative terms of trade effects associated with the dollar's decline almost offset the positive relative price effects. But since 1987, when the dollar stabilized at lower levels, the improvement has been extensive because by that time the terms of trade effects from the depreciation had been almost fully absorbed. Thus, only the positive lagged impact of lower relative U.S. prices remained. Between 1987 and the first half of 1990 , the 2.6 percent annual rate of growth in the United States was 
60 percent of the 4.4 percent annual rate of expansion in the rest of the world. This differential was nearly sufficient to compensate for the impact of different activity elasticities.

\section{Adjustment in Trade with Japan}

Conventional wisdom has it that while U.S.-European trade adjusted dramatically to changes in the exchange rate, U.S.-Japanese trade has experienced only minor adjustments. Indeed, many point to this alleged failure as reason to manage U.S.-Japanese trade. The evidence, however, does not support this argument.

Typically, those who claim Japanese trade has not adjusted to the dollar's depreciation rely on trade balance data. As reported in table 12, the bilateral U.S. trade deficit with Europe declined from a surplus of $\$ 20.6$ billion in 1980 to a deficit of $\$ 20.6$ billion in 1987, a total decline of $\$ 41.2$ billion. By the first half of 1990 , however, this balance had reverted to an annualized surplus of $\$ 10.5$ billion. By contrast, the bilateral deficit with Japan increased by $\$ 46.2$ billion between 1980 and 1987, more than the decline with Europe. Furthermore, the subsequent improvement in U.S.-Japanese trade has been quite minor; between 1987 and 1989 the deficit shrank by just $\$ 7.3$ billion from $\$ 56.3$ billion to $\$ 49.0$ billion. In addition, while Japan accounted for 37 percent of the overall U.S. trade deficit in 1987, it accounted for 45 and 42 percent of the deficit in 1988 and 1989 respectively.

What has been overlooked in this debate, however, is the fact that bilateral trade balances will be affected by both the level of the initial imbalance and the subsequent rate of adjustment. For example, in 1987 U.S. exports to Japan totaled $\$ 28.2$ billion and were one-third the size of U.S. imports from Japan; thus, U.S. exports to Japan would have had to grow three times as fast as imports from Japan, simply for the balance to remain unchanged. By contrast, in the same year U.S. exports to Europe equaled $\$ 60.5$ billion, or 74.5 percent of total U.S. imports from Europe. For the trade balance with Europe to remain unchanged, exports to Europe would have had to rise only 1.3 times as rapidly as imports. A large initial ratio of imports to exports, therefore, entails a slower adjustment in the deficit measure. Since 1987, changes in the bilateral 
Table 12. United States: Trade Performance, 1980-90

\begin{tabular}{|c|c|c|c|c|c|}
\hline & 1980 & 1985 & 1987 & 1989 & 1990 \\
\hline \multicolumn{6}{|l|}{ Trade balance (billions of dollars) } \\
\hline U.S.-world & -19.5 & -126.5 & -152.1 & -108.6 & -93.0 \\
\hline U.S.-Japan & -10.1 & -46.2 & -56.3 & -49.0 & -39.2 \\
\hline U.S.-Europe & 20.6 & -18.8 & -20.6 & 1.5 & 10.5 \\
\hline \multicolumn{6}{|l|}{ Exports } \\
\hline U.S. to world (billions of dollars) & 225.7 & 218.8 & 254.1 & 364.4 & 390.6 \\
\hline Percent to Japan & 9.2 & 10.3 & 11.1 & 12.2 & 12.1 \\
\hline Percent to Europe & 26.1 & 22.4 & 23.8 & 23.8 & 25.6 \\
\hline Ratio, Japan/Europe & 0.35 & 0.46 & 0.47 & 0.51 & 0.47 \\
\hline \multicolumn{6}{|l|}{ Imports } \\
\hline World to U.S. (billions of dollars) & 245.3 & 345.3 & 406.2 & 472.9 & 483.6 \\
\hline Percent from Japan & 12.6 & 19.9 & 20.8 & 19.8 & 17.8 \\
\hline Percent from Europe & 15.6 & 19.6 & 20.0 & 18.0 & 18.5 \\
\hline Ratio, Japan/Europe & 0.81 & 1.02 & 1.04 & 1.10 & 0.96 \\
\hline \multicolumn{6}{|l|}{ Manufacturing trade } \\
\hline \multicolumn{6}{|l|}{ Balance (billions of dollars) } \\
\hline U.S.-world & 27.7 & -90.1 & -124.5 & -103.2 & -77.8 \\
\hline U.S.-Japan & -21.5 & -55.8 & -67.6 & -66.9 & -55.4 \\
\hline \multicolumn{6}{|l|}{ Exports } \\
\hline U.S.-world (billions of dollars) & 160.7 & 167.8 & 200.0 & 276.4 & 300.2 \\
\hline Percent to Japan & 5.6 & 7.4 & 8.2 & 9.6 & 9.9 \\
\hline \multicolumn{6}{|l|}{ Imports } \\
\hline U.S.-world (billions of dollars) & 133.0 & 257.9 & 324.9 & 379.6 & 378.0 \\
\hline Percent from Japan & 22.9 & 26.4 & 25.8 & 24.6 & 22.5 \\
\hline
\end{tabular}

Source: U.S. Department of Commerce. Figures for United States in 1990 are annualized from January-June data. Figures for Japan in 1990 are annualized from January-May data. For 1989 and 1990, Japanese figures for manufacturing trade are based on Japanese trade data.

deficit with Japan actually say more about the initial ratio of exports to imports than any subsequent adjustment.

Indeed, as table 12 reports, between 1987 and the first half of 1990 , the dollar value of U.S. exports to Japan grew more rapidly than U.S. exports in general, and as rapidly as U.S. exports to Europe. Over the same period, U.S. imports from Japan grew less rapidly than U.S. imports in general, and U.S. imports from Europe in particular. Similarly, between 1987 and 1990 Japan accounted for a growing share of U.S. manufactured goods exports and a declining share of U.S. manufactured goods imports. In short, both export and import performance indicate that Japan has adjusted more than Europe and other trading partners of the United States. 
At the margin, Japanese imports respond to relative import price changes almost as sensitively as other countries. ${ }^{32}$ In addition, Japan shows signs of a structural shift toward higher import income elasticities. ${ }^{33}$ While this evidence does not necessarily imply the absence of unusual trade barriers, it does suggest that, if present, they operate like tariffs, which do not stifle marginal responses to exchange rate changes, rather than like quotas.

Finally, the use of Japan's share of the overall U.S. trade deficit as a measure of how much Japan has adjusted is highly misleading. Note that in 1980, when the United States had an overall trade deficit of $\$ 19.5$ billion, Japan accounted for 51.7 percent of the deficit. This feature of the trade balance results from a structural component of the bilateral deficit with Japan. Even if both Japan and the United States had balanced trade, Japan would probably still run a surplus with the United States in order to offset its deficit with OPEC. Paradoxically, the rising Japanese share in the overall U.S. deficit actually points to a return to these structural levels rather than a lack of adjustment to the dollar's depreciation.

\section{The Burden of the Debt}

In 1981, the United States was the world's largest net creditor nation. In table 13, which shows the U.S. net international investment position, American assets abroad in that year exceeded foreign assets in the United States by $\$ 141.1$ billion, and the United States earned a surplus of $\$ 31.3$ billion in net foreign income. Since 1981, the United States has become the world's largest net debtor nation, largely because it has run large trade deficits. ${ }^{34}$ By the end of 1989 , the net investment position of the United States was $-\$ 620.2$ billion. In the first half of 1990 , U.S. net foreign income had shrunk to an annual rate of just $\$ 2.4$ billion. ${ }^{35}$

What is really surprising about these numbers, however, is how little U.S. net foreign earnings have fallen. Even though Americans borrowed

32. See Lawrence (1987) and Bosworth (1990).

33. See Petrie (forthcoming) and Lawrence (forthcoming).

34. For a more extensive discussion of this concept, see Islam (1988).

35. Because of data problems, some of which are discussed below, the BEA stopped publishing the net international investment position in 1988, although it still reports component details. See Scholl (1990). 


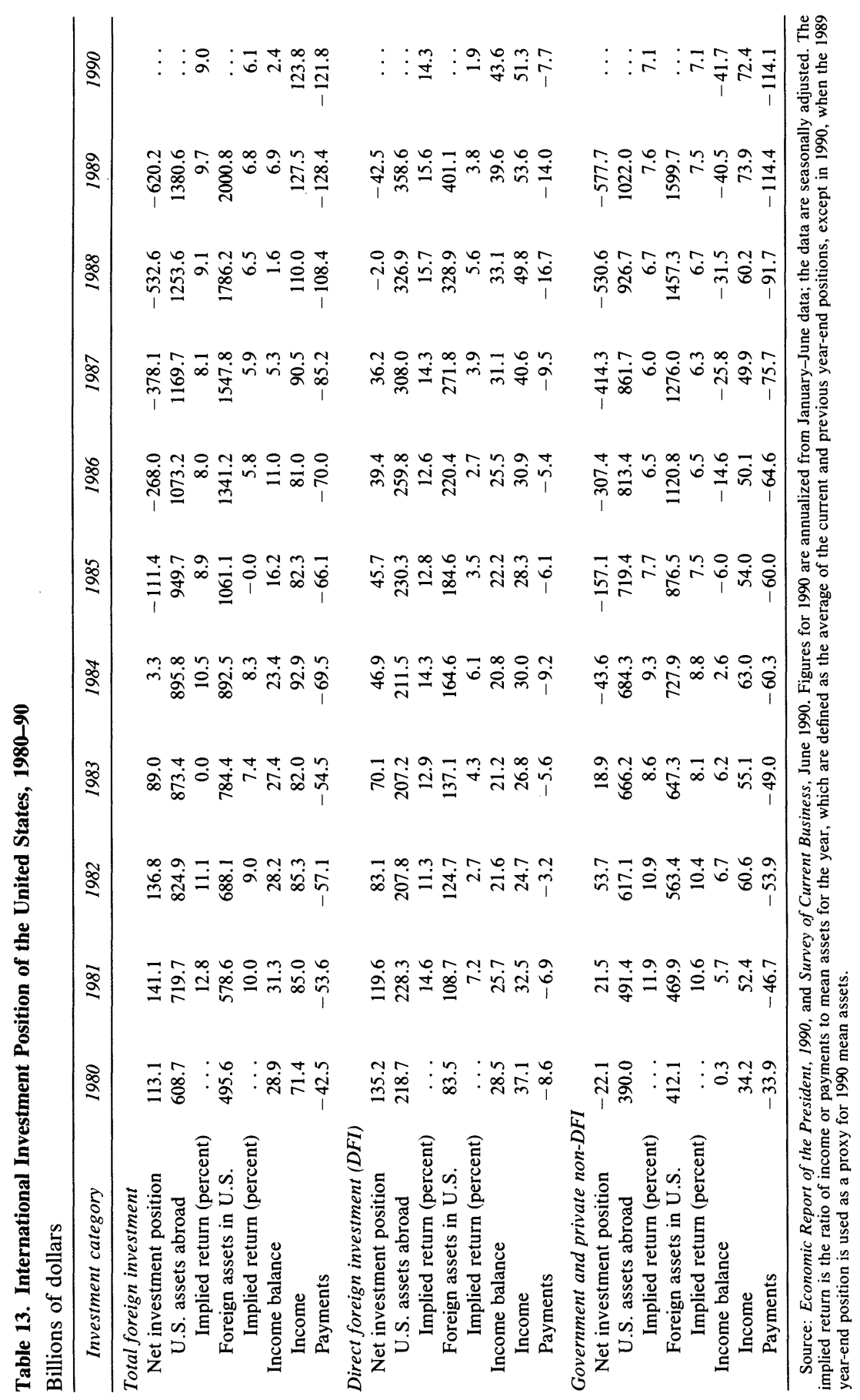


$\$ 761.3$ billion from foreigners, their net annual payments increased by just $\$ 24.4$ billion-suggesting an annual interest rate burden of just 3.2 percent. To understand this result, one must distinguish between the behavior of both payments on the net debt that has been borrowed by the U.S. public sector, by banks, and by the private sector, and payments on the net direct foreign investment (DFI).

\section{Debt}

There is no real surprise in the payments on debt. The crude rule of thumb-a method that works reasonably well-applies a single rate of interest to changes in the net position. More precise estimates require taking account of two key elements that lead to a higher return on U.S. private, nondirect foreign investment assets than on U.S. liabilities. First, because U.S. banks generally aim to earn profits, rates of return on the foreign assets of U.S. banks tend to be higher than the rates of interest paid by U.S. banks to foreigners. Second, estimates of returns on stocks are low because they ignore capital gains. The fact that foreign holdings in the United States have a higher proportion of stocks than U.S. holdings abroad contributes to the higher reported return on U.S. assets abroad.

Between 1981 and 1989, Americans assumed a net additional $\$ 599.2$ billion in private and government non-DFI debt; their net payments on this debt increased by $\$ 46.2$ billion. This indicates an average incremental cost of 7.7 percent, which conforms to the rule-of-thumb procedure. ${ }^{36}$

\section{Direct Foreign Investment}

An unexpected finding, however, lies in the net earnings from direct foreign investment. Between 1981 and 1989, foreigners invested $\$ 162.0$ billion more in the United States than Americans invested abroad. By 1988, the United States was a net debtor in direct foreign investment. Yet, between 1981 and 1989 U.S. net earnings from direct investment actually increased by $\$ 13.9$ billion.

One part of the explanation is that the official data severely understate the real value of U.S. assets abroad, investments being reported at their

36. Some caution is warranted in interpreting this figure because banks that carry developing country debt as assets may have difficulty collecting on the debt. 
historic rather than replacement cost. ${ }^{37}$ Given inflation and the depreciation of the U.S. dollar, U.S. asset holdings are much larger than officially estimated. At the end of 1988, for example, Lois Stekler and William Helkie estimated that U.S. DFI assets abroad were $\$ 742$ billion, rather than the BEA book value of $\$ 322$ billion. ${ }^{38} \mathrm{U}$.S. earnings on DFI of $\$ 49.8$ billion in 1988 imply a more plausible rate of return of 7.2 percent, if U.S. DFI mean assets for 1988 are calculated as the mean of Stekler and Helkie's 1987 and 1988 estimates. Their estimates suggest that at the end of 1988 the U.S. net investment position was $-\$ 190$ billion rather than the official $-\$ 533$ billion.

A second part of the net earnings picture is more intriguing. It appears that foreign investment in the United States has been extraordinarily unprofitable. Between 1981 and 1989, foreigners spent $\$ 292.4$ billion acquiring equity positions in U.S.-based firms and setting up their own subsidiaries. Yet their earnings in 1989 were only $\$ 7.1$ billion higher than they were in 1981. All told, the rate of return on foreign direct investment in the United States was 5.6 percent in 1988 , and only 3.8 percent in 1989. Because these estimates are based on a historic cost basis, they overstate the rate of return that would have resulted had inflation been taken into account. Indeed, the Stekler-Helkie estimates of foreign assets in the United States suggest a return of 4.5 percent in 1988. In 1987 , the ratio of income to equity for U.S. manufacturing was 12.8 percent while the return to foreign direct investment in manufacturing, valued at historic cost, was just 5.9 percent. Measures of income to sales confirm the picture. Between 1983 and 1987, the income-sales ratio on foreign investment in U.S. manufacturing was 1.2 percent, less than half the average income-sales ratios for U.S. domestic manufacturers (4.2 percent) and U.S. direct investment abroad (3.6 percent).

One interpretation of these data is that American managers care more about profits than foreign managers. This conclusion could, in turn, indicate that American-owned firms face a higher cost of capital, although this explanation contradicts the fact that foreign-owned firms in the United States tend to finance their operations locally. A second interpretation is that foreign investment in the United States is a relatively

37. For more extensive discussions see Eisner and Pieper (1990); Ulan and Dewald (1989); and Scholl (1990).

38. Stekler and Helkie (1989, p. 14b). Eisner and Pieper (1990, p. 17) estimate the market value of U.S. direct investment abroad in 1988 at $\$ 748.9$ billion. 
new phenomenon and will take time to become more profitable. However, this interpretation may not be fully credible because returns on foreign investment in the United States have been low for a long time now. Finally, there is the possibility that the data are erroneous, possibly because foreigners deliberately underreport their earnings in the United States for tax or other purposes.

For some foreign investors, particularly foreign governments, the incentive to underreport income is presumably high. Why pay tax to the United States if you can avoid it? The underreporting is most likely achieved by overstating the costs of imported components-a practice known as transfer pricing. Transfer pricing should not affect the overall U.S. current account but can lead to an overstatement of import values and an understatement of payments on DFI. However, if tax evasion is the reason that companies engage in transfer pricing, it is surprising that the practice would have persisted despite the reduction in U.S. corporate tax rates in 1986. Companies from countries that do not tax their multinationals on a global basis should have an incentive to report income in the United States rather than at home. Nevertheless, whatever the reason, the decline in the U.S. current account has not been as large as might have been expected.

Table 14 indicates that, with the exception of the finance and insurance industries, the low returns are pervasive. The table also shows especially low returns for investors from Germany, France, Japan, Latin America, and the Middle East, and higher returns for investors from Switzerland, the United Kingdom, the Netherlands, and Canada.

\section{Inflation}

Just as gross domestic product (GDP) ignores depreciation on domestically held assets, so may it be appropriate for gross national product (GNP) to ignore depreciation on foreign-held assets. Nevertheless, it is certainly appropriate, when using other measures of national product, to account properly for changes in the real value of U.S. net debt. Indeed, erosion in the real value of U.S. net debt means that the increase in the real debt-servicing burden has been much less than reported by the net-factor income measure. The official data fail to differentiate between interest payments on debt, which represent genuine servicing payments, and those that actually compensate owners for the inflationary 
Table 14. Equity, Sales, and Income of Direct Foreign Investment in the United States, 1987

\begin{tabular}{|c|c|c|c|c|c|}
\hline & $\begin{array}{c}\text { Net income } \\
\text { (billions of } \\
\text { dollars) }\end{array}$ & $\begin{array}{c}\text { Sales } \\
\text { (billions of } \\
\text { dollars) }\end{array}$ & $\begin{array}{c}\text { Incomel } \\
\text { sales } \\
\text { (percent) }\end{array}$ & $\begin{array}{c}\text { Equity } \\
\text { (billions of } \\
\text { dollars) }\end{array}$ & $\begin{array}{c}\text { Incomel } \\
\text { equity } \\
\text { (percent) }\end{array}$ \\
\hline Total direct foreign investment & 9.9 & 731.4 & 1.3 & 217.8 & 4.5 \\
\hline \multicolumn{6}{|l|}{ By industry } \\
\hline Petroleum & 1.3 & 74.5 & 1.8 & 26.2 & 5.0 \\
\hline Manufacturing & 4.9 & 220.7 & 2.2 & 83.5 & 5.9 \\
\hline Wholesale & 0.4 & 273.9 & 0.1 & 25.4 & 1.6 \\
\hline Retail trade & -0.1 & 47.2 & -0.2 & 8.0 & -1.3 \\
\hline Finance $^{b}$ & 2.7 & 26.5 & 10.0 & 18.9 & 14.1 \\
\hline Insurance & 1.9 & 39.1 & 4.8 & 22.8 & 8.3 \\
\hline Real estate & -0.6 & 10.5 & -6.2 & 14.5 & -4.5 \\
\hline Services & -0.6 & 18.0 & -3.3 & 9.0 & -6.6 \\
\hline Other & 0.0 & 21.0 & 0.0 & 9.6 & 0.1 \\
\hline \multicolumn{6}{|l|}{ By investing region or nation } \\
\hline Canada & 2.0 & 89.3 & 2.3 & 37.5 & 5.4 \\
\hline Europe & 7.1 & 387.0 & 1.8 & 120.4 & 5.9 \\
\hline United Kingdom & 4.6 & 130.4 & 3.5 & 42.5 & 10.7 \\
\hline Netherlands & 1.3 & 52.1 & 2.4 & 22.7 & 5.5 \\
\hline Switzerland & 0.7 & 37.6 & 1.9 & 9.7 & 7.5 \\
\hline Germany & -0.2 & 72.2 & -0.2 & 20.8 & -0.9 \\
\hline France & -0.1 & 43.5 & -0.2 & 10.4 & -0.8 \\
\hline Asia and the Pacific & 0.6 & 206.1 & 0.3 & 36.7 & 1.6 \\
\hline Japan & 0.5 & 182.3 & 0.3 & 25.6 & 1.9 \\
\hline Latin America & -0.4 & 27.1 & -1.5 & 6.0 & -7.0 \\
\hline Middle East & -0.8 & 5.8 & -14.1 & 7.4 & -11.0 \\
\hline Other & 1.4 & 16.1 & 8.5 & 9.8 & 14.1 \\
\hline
\end{tabular}

Source: Bureau of Economic Analysis, U.S. Department of Commerce, Foreign Direct Investment in the U.S., 1987 Benchmark Survey: Preliminary Results, tables 5, 8, B-2, B-4. Figures represent all U.S. affiliates of foreignowned firms, and U.S. firms with over 10 percent foreign ownership, with sales or equity over \$1 million in 1987.

a. Equity is given as "total owner's equity."

b. Finance represents all nonbanking financial activities.

erosion of the value of their assets. In a world of 4 percent inflation, an 8 percent interest payment on debt to foreigners should be treated as a 4 percent nominal payment and a 4 percent capital outflow (or repayment). The magnitude of this effect for the United States can be roughly calculated by estimating the annual decline in the real value of U.S. net international debt obligations. Table 15 reports net debt positionscalled net debt instruments-which exclude the holding of equity. The U.S. net debt instrument position is calculated by excluding the foreign stock holdings of Americans and the stock holdings of foreigners in the United States, on the grounds that these assets should move with inflation. Similarly, U.S. gold holdings are excluded. 


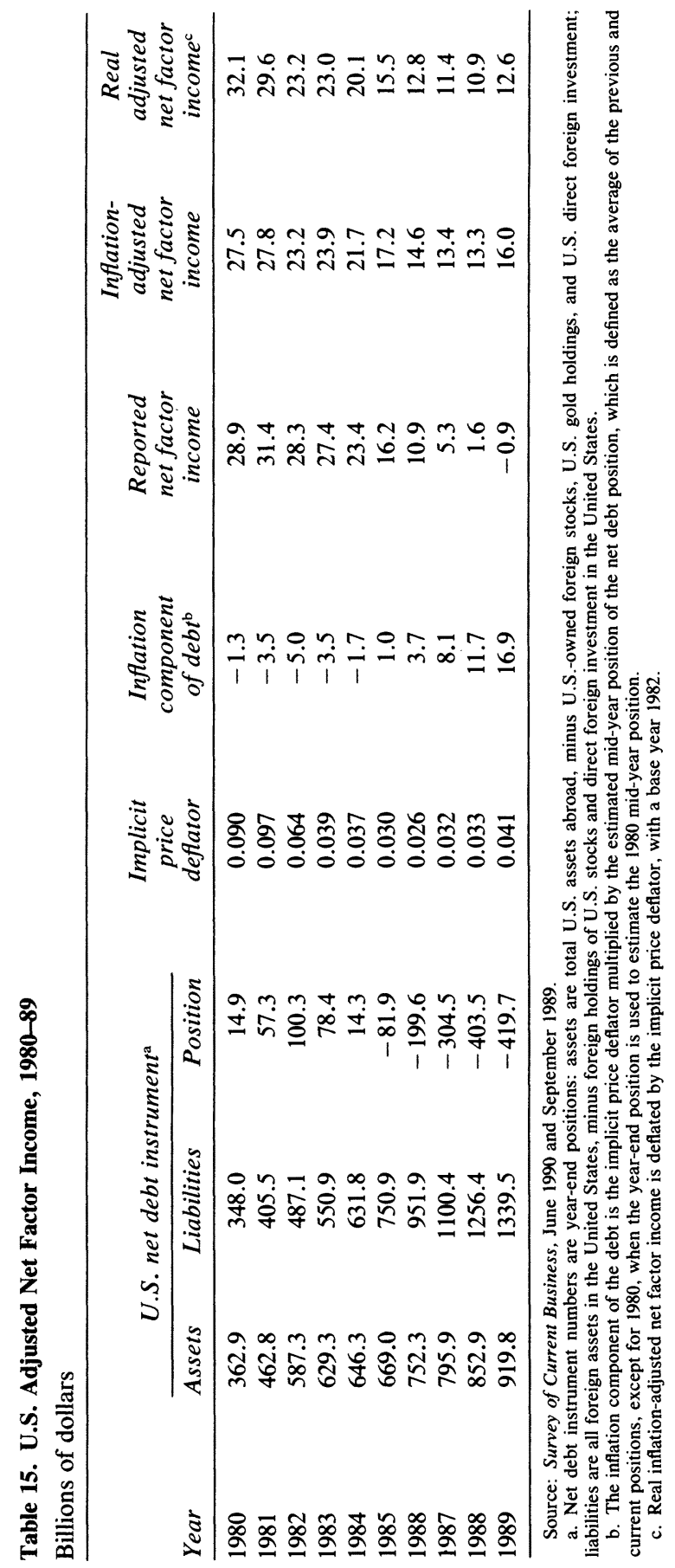


How does one decide what price index to use when estimating the impact of inflation? One guide is the currency in which the debt is denominated. In the case of the United States, roughly 80 percent of foreign debt assets and liabilities are denominated in dollars. ${ }^{39}$ Thus, a dollar price index is reasonably suitable for a first pass at estimating the size of this effect. Because debt earnings and payments in the GNP accounts are deflated by the GDP deflator, it seems appropriate to use the GDP deflator for calculating the effect. The results of this adjustment are reported in table 15. In 1980, the United States had a positive net debt instruments position of $\$ 14.9$ billion, and nominal net factor income was $\$ 28.9$ billion. Given the inflation rate of 9 percent, there was also an erosion of $\$ 1.3$ billion in the value of the outstanding assets. In 1989 , when net factor payments were $-\$ 0.9$ billion, the 4.1 percent inflationary erosion on outstanding U.S. obligations was worth $\$ 16.9$ billion. Table 15 also shows that the adjusted net factor income in 1989 was $\$ 16.0$ billion, only $\$ 11.5$ billion lower than the adjusted net factor income of $\$ 27.5$ billion in 1980 . Measured in 1982 dollars, real net factor income in 1989 was $\$ 12.6$ billion, $\$ 19.5$ billion less than in 1980 .

The remarkable fact, therefore, is that while the United States has become a large nominal net debtor over the decade, the real burden of the debt has grown by relatively little. This should not be that surprising. In a world with real interest rates of about 3 percent, borrowing an additional $\$ 600$ billion will result in real interest payments of $\$ 18$ billion, which represent less than 0.4 percent of U.S. national income..$^{40}$ Moreover, additional earnings from U.S. net foreign direct investment have been sufficient to offset the real costs of additional U.S. borrowing. This finding underscores the conclusions of those who have argued that U.S. net foreign borrowings can be sustained.

\section{Conclusions}

The mysteries about recent U.S. trade performance lie in the data, not in actual behavior. Once computers are excluded, conventional

39. At the end of 1989 , for example, U.S. banks' liabilities payable in dollars were 80.8 percent of their total liabilities. Their claims in dollars were 81.4 percent of their total claims. See Survey of Current Business, June 1990, pp. 58, 54.

40. For a more extensive treatment see Lawrence (1988). 
explanations for changes in the U.S. NONA trade balance hold. Over the last decade, we have observed something close to a controlled experiment. The real, effective dollar exchange rate at the end of the decade roughly equals its level at the start of the decade. Growth in real U.S. spending has been similar to growth in real spending abroad, but the NONA balance in goods and services in the first half of 1990 was $\$ 70.9$ billion lower than in 1980 . This outcome is well explained by the regression results.

The pricing behavior of U.S. exporters and of foreigners who export to the United States has been predictable. Relative export and import prices have responded symmetrically to the dollar's rise and fall. Following the real exchange rate, relative prices had returned to their 1980 levels by the first half of 1990 . Thus, when the lagged impact of relative price changes are taken into account, they play no role in explaining changes in the trade balance over the decade.

Given relative prices, the coefficients in the regressions imply that if the United States grows at 2.5 percent, then nonagricultural exports will match the growth rate in nonoil imports when growth abroad reaches 4.1 percent ${ }^{41}$ For each percentage point that foreign growth falls short of this growth rate, the real exchange rate would have to be 1 percent lower in order to keep exports and imports growing at the same rate. The decline in the NONA balance is a measure of the erosion in U.S. competitiveness over the decade. For the NONA balance to have returned to its 1980 nominal level, the real effective exchange rate would have had to be about 10 percent weaker over the past three years. ${ }^{42}$

Regression equations fitted between 1976 and 1984 can account for U.S. trade performance over the following five years. Given foreign growth and relative export prices, predicted and actual growth in U.S. xport volumes and prices have tracked each other closely. Over the

41. The growth estimate of 2.5 percent for the United States seems a reasonable estimate of its current long-run potential. See Litan, Lawrence, and Schultze (1988), and Garner (1989). For a more optimistic view, see the Economic Report of the President (1990).

42. Returning the NONA coverage ratio to its 1980 level, a more difficult task, would require a depreciation of roughly 13 percent. The adjustment of the real effective exchange rate must, of course, be accompanied by changes in the nation's savings and investment flows. The choice of mechanisms by which the dollar's depreciation is achieved will have a major impact on the path of the trade balance. 
past eighteen months, there is evidence that U.S. imports are growing more slowly than expected.

In summary, there is modest support for those who believe direct foreign investment and other factors may have reduced the U.S. propensity to import, but there is little support for the pessimists who have claimed that U.S. trade flows would not respond to exchange rate changes. In particular, conventional wisdom about Japanese trade adjustment is incorrect. Judged, as it should be, by the growth rates of Japanese imports and exports, U.S.-Japanese trade has actually adjusted more rapidly than either total U.S. trade or trade with Europe alone.

The behavior of net factor income in the United States does contain surprises. The apparent average rate of return to direct foreign investment in the United States has been very low, keeping net factor income from changing much despite a decade of large current account deficits. If one corrects the value of the U.S. net debt for inflation, the additional international debt, measured in real terms, assumed by the United States over the 1980s has resulted in a surprisingly small increase in real U.S. international debt-service burdens. 


\section{Comments and Discussion}

Peter Hooper: Robert Lawrence's paper makes four basic points. First, conventional empirical modeling of U.S. trade flows has been complicated by the Bureau of Economic Analysis's hedonic price index for computers. Second, the behavior of U.S. trade and current account balances through the first half of 1990 can be reasonably well explained by the conventional models, whether or not they make special adjustments for computers. One doesn't need to resort to unfair trade practices or hysteresis to explain the continuing U.S. external deficit.

Third, the widening of the U.S. external deficit over the past decade presents a bit of a mystery, since U.S. GNP has grown no more than foreign GNP over that period and the dollar's real exchange rate is now almost back to its 1980 level. Lawrence's explanation is based on the familiar Houthakker-Magee result-that the trade deficit widens because the income elasticity of imports is substantially greater than that of exports.

Fourth, even given a widening deficit, there is no need for concern because the large cumulative external deficits run over the past decade have resulted in almost no increase in the real U.S. international debt service burden.

While I enjoyed the paper, I also found ample room for disagreement with several of the points that were made. I will begin with the discussion of computers. As Lawrence points out, BEA's treatment of computer prices, as measured by the hedonic index, is potentially misleading because it assumes that the prices of imports, exports, and domestic shipments of computers are all one and the same. BLS data suggest, to the contrary, that movements in the prices of computer imports and exports have diverged from one another. Lawrence concludes that the 
BLS data are preferable. However, those data may significantly overstate increases in the prices of both imports and exports of computers because they do not factor in the tremendous technological advances that have taken place over the past decade. They still price by the box, if you will, rather than by the power or the capability of the box.

Using BLS data, Lawrence constructs a set of new aggregate price indexes for imports and exports. The series that he constructs are neither fixed-weight indexes nor deflators (which use moving-quantity weights). Instead he uses moving-value weights, which, in principle, could impart an inflationary bias to those indexes. With moving-value weights, trade categories in which prices rise faster than average will tend to get an increasing weight over time, other things being equal, while those categories in which prices are rising slower than average will be given decreasing weight.

Lawrence is careful not to use his indexes to deflate trade values for use in his import and export quantity equations; to do so would be inappropriate. But then one wonders why he constructed his price indexes in the first place; why not just use the BLS fixed-weight index, or at least construct a deflator using volume weights?

I fully agree with Lawrence that the exclusion of computers makes it easier to explain the movements in BEA's measures of the prices and volumes of imports and exports in recent years. This adjustment is helpful for the type of historical accounting exercise that he pursues in the paper. However, this adjustment does not help much when models are put to the more stringent test of policy simulation and forecastingthat is, when trade in computers can no longer be treated exogenously. In modeling work at the Federal Reserve, we have found that because of difficulties encountered in estimating equations for trade in computers, one can do just as well predicting total trade flows with aggregate equations as with disaggregated equations.

A final point on computers. I was struck that the rather lengthy treatment of this issue in the paper stands alone; the implications of computer prices for trade modeling do not seem to have much bearing on the more central issue of external adjustment raised elsewhere in the paper. Lawrence points out elsewhere in the paper that conventional models that do not adjust for computers (in particular those surveyed by Ralph Bryant) appear to have done reasonably well in predicting the trade balance. I might note that several other models that $d o$ adjust for 
computers, including the one we have been working with at the Federal Reserve, have been overpredicting the trade deficit by a considerable margin recently, particularly by overpredicting imports. Indeed, Lawrence's own equations that exclude computers overpredicted imports by an increasingly significant margin during 1989-90.

Next, let me turn to the mystery surrounding the widening of the external deficit over the 1980s and Lawrence's explanation for it based on the Houthakker-Magee result. The mystery emerges only in the process of accounting with partial-equilibrium trade models. That accounting asks why the external deficit should be any greater now than in 1980 , since its key determinants-relative income and relative pricesare back to where they were in 1980 .

From the more fundamental perspective of exogenous shifts in domestic saving and investment, the persistence of an external deficit should come as no surprise. The U.S. structural or full employment budget deficit is now much greater than it was in 1980, and the personal saving rate remains well below its level of ten years ago. In fact, one might wonder why the external deficit continued to narrow as rapidly as it did through the first half of this year.

In a general-equilibrium framework, of course, exogenous shifts in saving and investment are transmitted to trade flows through changes in income (or domestic demand) and relative prices. So the picture we get from trade equations should be consistent. I will argue that it is. U.S. GNP may have grown about the same as foreign GNP over the past decade, but U.S. domestic demand, or $C+I+G$, has risen about 4 percentage points more than that abroad. If domestic demand were the key activity variable in trade equations, the difference in demand alone could explain most of the net widening of the deficit. In addition, while the dollar's real exchange rate may have returned to its 1980 level (at least by some measures), the relative prices of imports and exports that enter into trade equations have not. In the Federal Reserve's model, the price of imports relative to domestic U.S. prices has fallen somewhat more over the past ten years than the price of exports relative to domestic prices abroad. Thus, imports have been stimulated more than exports by movements in relative prices.

But let us suppose that GNP is the relevant activity variable, and that most of the net increase in the trade deficit is left unexplained by movements in relative prices. The Houthakker-Magee result is only one 
of several plausible explanations for the observation that U.S. imports tend to grow faster than U.S. exports, other things being equal. In a paper presented to this panel several years ago, Paul Krugman and Richard Baldwin argued that after accounting for the influences of income and relative prices, the U.S. trade balance tended to show a secular decline. ${ }^{1}$ They attributed this decline and an associated secular decline in the dollar's real exchange rate to the lagging productivity growth and the diminishing technological edge of the United States relative to its trading partners.

Some of my colleagues and I have, for some time, been working under the assumption that the Houthakker-Magee result really reflects longerterm supply-side developments. These developments are inadequately represented in movements in relative price variables but at the same time are strongly correlated with longer-term trends in GNP. We have found that adding supply proxies to the equations significantly reduces the difference in estimated income elasticities.

Just how one views this empirical issue can affect one's view of the future prospects of the external deficit. For example, a slowing of U.S. growth relative to growth abroad could have a strong effect on the trade deficit if the income elasticity of the demand for imports is as high as Lawrence estimates. However, if part of that high elasticity actually reflects the effects of trends in foreign supply, the effect of lower domestic growth would be smaller. Lawrence, who cites Ellen Meade's work as important, observes that the significance of relative supply variables in trade equations falls when computers are taken out. However, they do remain at least marginally significant in Meade's import equation and they are quite significant when computers are removed.

Several years ago, I argued that the sharp decline in the dollar could stimulate ongoing supply-side shifts that would begin to reverse the secular downtrend in the U.S. external balance. As Lawrence notes, there is some evidence in the recent improvement in the trade balance to support this view. However, the supply-side view also predicted that we would begin to see a shift in manufacturing output capacity toward the United States. This part of the prediction does not appear to have been realized; the effects of the decline in the dollar have been dominated by other factors that have led to an investment boom abroad and not at home.

1. Krugman and Baldwin (1987). 
The paper concludes on an optimistic note about the effect of the large cumulative U.S. external deficits over the past decade on the U.S. real debt burden. The decline in U.S. real net foreign investment income caused by the increase in U.S. net debt to foreigners has been relatively small. According to the estimates presented, U.S. real net foreign income adjusted for inflation fell from over 1 percent of GNP in 1980 to about 0.25 percent of GNP in 1989. Some would argue that a decline equal to 0.75 percent of GNP is not trivial. Moreover, these estimates probably understate the potential future costs of the debt that has already been accumulated. As Lawrence points out, U.S. residents have benefited from a substantially greater rate of return on their direct investment assets abroad than what they pay on foreign-held direct investment in the United States. The rate of payment on foreign direct investment in the United States has been unusually low and has declined further recently, for any number of reasons. But at least some of those reasons, including the cyclical decline in U.S. domestic growth and corporate profits over the past year and a half, are likely to be reversed in the future. When rates of return eventually begin to rise toward more normal levels, the real burden of the external debt incurred by the United States over the past decade will increase as well.

\section{General Discussion}

Robert Barro questioned the author's basic approach. He argued that it is inappropriate to estimate equations for imports and exports without taking into account the fact that current account balances are the difference between a country's production and expenditures, or, equivalently, the difference between domestic saving and investment. These flows are connected by an intertemporal budget constraint that also involves the initial stock of net foreign claims. Hence, he believed that the current account deficit can be traced back to the incentives for saving and investment. Martin Baily responded that although the federal deficit has had a major influence on the trade deficit, it presumably works by affecting national income, the exchange rate, and relative prices. Therefore, apart from possible estimation difficulties arising from endogeneity, he found nothing wrong with focusing on how those variables affected imports and exports without estimating the whole model. He did suggest, however, that the estimates might be affected if the domestic component of demand were used in place of GNP. 
The reported low rate of return earned on direct foreign investment provoked discussion among the panelists. William Brainard urged caution in interpreting the estimates. He found it unlikely that foreigners systematically selected worse investments than the typical American investor, indeed so much worse that their return has been lower than the return on government securities. Baily suggested that the low returns could be the result of transfer pricing policies designed by foreign investors to generate profits at home. He noted that if imported factors of production are being systematically overpriced then imports are being overstated. William Cline added that the plausible alternative assumptions about rates of return have a major effect on projections of the current account deficit a few years out. Cline and Robert Gordon both expressed misgivings about the Houthakker-McGee effect, especially in light of recent work by Paul Krugman that suggests that it is impossible to disentangle income elasticities from time trends.

Gordon noted that using the BEA deflator for computer prices doubles the current weight attributed to computers in GNP relative to the base year of 1982. Further, use of the BEA deflator gives them virtually zero weight before 1975 . He did not agree, however, that it is correct to use the BLS deflator instead, since it does not correct for changes in performance. He recommended use of chain-weight or fixed-weight deflators. Also, he noted that the problems with the BLS measure are not limited to computers because the BLS makes inadequate quality adjustments for many components. Gordon pointed out that other countries do not use similar computer deflators; the much greater growth rate of U.S. computer output, due largely to this measurement difference, helps to explain why measured productivity in the United States has grown so much faster in the manufacturing than in the nonmanufacturing sector, whereas in other countries the sectoral growth rates are much closer together.

Cline observed that some policymakers have been dismissive of model-based predictions of the current account deficit. He applauded the paper for challenging that assertion. He agreed with the emphasis on slow growth as an explanation for the change in deficit, noting that the recent reduction in the trade deficit is a sign of weakness rather than strength. He also agreed that the dollar needs to decline about another 10 percent to reestablish equilibrium.

Gordon noted that since the exchange rate is back where it was in 
1980 , and income growth here and abroad have been roughly the same over the past decade, the $\$ 80$ billion deterioration in the U.S. current account may be the result of other forces. He felt the paper needed a discussion of what these other forces were, and whether they were oneshot or trend phenomena. Robert Lawrence believed that the principal cause of the change in the current account has been a diffusion of U.S. technology to the rest of the world. He maintained that this effect should diminish over time. 


\section{References}

Alterman, William. Forthcoming. "Price Trends in U.S. Trade: New Data, New Insights." In International Economic Transactions: Issues in Measurement and Empirical Research, edited by Peter Hooper and J. David Richardson. Chicago: University of Chicago Press, for NBER.

Baldwin, Richard. 1988. "Hysteresis in Import Prices: The Beachhead Effect." American Economic Review 78: 773-85.

Bhagwati, Jagdish. 1988. "The Pass-Through Puzzle: The Missing Prince from Hamlet." Columbia University. Reported in "Passing the Buck," Economist, February 11, 1989.

Bosworth, Barry. 1990. “Managing Current Account Imbalances." Washington: Brookings (June).

Bryant, Ralph D. 1988. "The U.S. External Deficit: An Update." Brookings Discussion Papers in International Economics 63. Washington: Brookings (January).

$\rightarrow$ Citrin, Daniel. 1989. "The Recent Behavior of U.S. Trade Prices.' IMF Staff Papers 36: 934-49.

Cline, William R. 1989. United States External Adjustment and the World Economy. Washington: Institute for International Economics.

Dixit, Avinash. 1989a. "Entry and Exit Decisions under Uncertainty.' Journal of Political Economy 97: 620-38.

- 1989b. "Hysteresis, Import Penetration, and Exchange Rate PassThrough."' Quarterly Journal of Economics 104: 205-28.

Economic Report of the President. 1990 (February).

Eisner, Robert, and Paul J. Pieper. 1990. "The World's Greatest Debtor Nation?" North American Review of Economics and Finance 1: 9-32.

Garner, C. Alan. 1989. "How Fast Can the U.S. Economy Grow?" Federal Reserve Bank of Kansas City, Economic Review 74: 24-39.

Goldstein, Morris, and Moshin S. Khan. 1985. "Income and Price Effects in Foreign Trade." In Handbook of International Economics, Volume 2, edited by Ronald W. Jones and Peter B. Kenen. New York: North-Holland.

Hooper, Peter. 1989. "Exchange Rates and U.S. External Adjustment in the Short Run and the Long Run." International Finance Discussion Paper 347. Washington: Federal Reserve Board (March).

Hooper, Peter, and Catherine L. Mann. 1989. "Exchange Rate Pass-Through in the 1980s: The Case of U.S. Imports of Manufactures.' $B P E A, 1: 1989$, 297-329.

Houthakker, H. S., and Stephen P. Magee. 1969. "Income and Price Elasticities in World Trade." Review of Economics and Statistics 51: 111-25.

Islam, Shafiqul. 1988. "America's Foreign Debt: Fear, Fantasy, Fiction, and Facts." In The Dollar and the Trade Deficit: What's to be Done? edited by Alfred Reifman and Craig Elwell. Report 881-1430E. Washington: Congressional Research Service, Library of Congress. 
Krugman, Paul R. 1989a. Exchange-Rate Instability. Cambridge, Mass.: MIT Press.

- 1989b. "Differences in Income Elasticities and Trends in Real Exchange Rates." European Economic Review 33: 1031-46.

Krugman, Paul R., and Richard E. Baldwin. 1987. "The Persistence of the U.S. Trade Deficit." BPEA, 1:1987, 1-43.

Lawrence, Robert Z. 1987. "Japanese Imports: Closed Markets or Minds?" BPEA, 2:1987, 517-48.

- 1988. “The International Dimension." In American Living Standards: Threats and Challenges, edited by Robert E. Litan, Robert Z. Lawrence, and Charles L. Schultze. Washington: Brookings.

- Forthcoming. "How Open Is Japan?" In The U.S. and Japan: Trade and Investment, edited by Paul R. Krugman. Cambridge, Mass.: National Bureau of Economic Research.

Litan, Robert E., Robert Z. Lawrence, and Charles L. Schultze (eds.). 1988. American Living Standards: Threats and Challenges. Washington: Brookings.

Mann, Catherine L. 1990. "Prospects for Sustained Improvement in U.S. External Balance: Structural Change versus Policy Change." International Finance Discussion Paper 373. Washington: Federal Reserve Board (January).

Marquez, Jaime. 1988. "Income and Price Elasticities of Foreign Trade Flows: Econometric Estimation and Analysis of the U.S. Trade Deficit." International Finance Discussion Paper 324. Washington: Federal Reserve Board (June).

Marquez, Jaime, and Neil R. Ericsson. 1990. "Evaluating the Predictive Performance of Trade-Account Models." International Finance Discussion Paper 377. Washington: Federal Reserve Board (March).

McKinnon, Ronald I. 1984. An International Standard for Monetary Stabilization. Washington: Institute for International Economics.

Meade, Ellen E. Forthcoming. "Computers and the Trade Deficit: The Case of Falling Prices." In International Economic Transactions: Issues in Measurement and Empirical Research, edited by Peter Hooper and J. David Richardson. Chicago: University of Chicago Press, for NBER.

Organization for Economic Cooperation and Development. Main Economic Indicators. Various issues. Paris: OECD.

Parker, Robert P., and Leo M. Bernstein. 1990. "Deflation of Exports and Imports.' ' Paper Prepared for Workshop on Price Measurements and Their Uses, Conference on Research in Income and Wealth. Washington (March).

Petrie, Peter. Forthcoming. "Japanese Trade in Transition: Hypotheses and Recent Evidence." In The U.S. and Japan: Trade and Investment, edited by Paul R. Krugman. Cambridge, Mass.: National Bureau of Economic Research.

Sachs, Jeffrey D. 1988. "Global Adjustments to a Shrinking U.S. Trade Deficit." BPEA, 2:1988, 639-67. 
Scholl, Russell B. 1990. "International Investment Position: Component Detail for 1989.' Survey of Current Business 70 (June): 54-65.

Stekler, Lois E., and William L. Helkie. 1989. "Implications for Future U.S. Net Investment Payments of Growing U.S. Net International Indebtedness." International Finance Discussion Paper 358. Washington: Federal Reserve Board (July).

Ulan, Michael, and William G. Dewald. 1989. "The U.S. Net International Investment Position: Misstated and Misunderstood.' In Dollars, Deficits, and Trade, edited by James A. Dorn and William A. Niskanen. Boston: Kluwer Academic Publishers, for the Cato Institute. 